\title{
El coro y las vidrieras de la iglesia alta del Monasterio de Santa Engracia de Zaragoza. Nuevas aportaciones
}

\author{
The choir and the stained-glass windows of the \\ high church of the Monastery of Saint Engracia \\ from Zaragoza. New contributions
}

\author{
Ana María ÁGREDA PINO \\ Universidad de Zaragoza \\ Jorge ANDRÉS CASABÓN \\ Archivo Capitular de La Seo de Zaragoza
}

REsumen: El monasterio de Santa Engracia, en la ciudad de Zaragoza, fue uno de los conjuntos artísticos más notables de Aragón a lo largo de la Edad Moderna, desaparecido en su mayor parte durante el Primer Sitio de la ciudad en la Guerra de la Independencia. El hallazgo de nuevos datos documentales ha permitido reconstruir parte del proceso de edificación de una de las zonas más significativas de la iglesia monástica, el coro alto. Esta documentación desvela las peculiaridades de un espacio fundamental en la vida de los monjes jerónimos; amplía nuestra información sobre la presencia del arte de la vidriera en Aragón y aporta nuevos datos sobre los artistas encargados de llevar a cabo los trabajos: el escultor Pedro Laguardia y el vidriero Francisco de Valdivieso.

Palabras clave: Monasterio de Santa Engracia, Vidrieras, Coro, Pedro Laguardia, Francisco de Valdivieso.

AвstRACT: Santa Engracia 's Monastery, in the city of Zaragoza, was one of the most prominent historic-artistic grouping in Aragon throughout the Modern Age, mostly disappeared during the first Sitio of the city in the Spanish War of Independence. Finding new documentary data has allowed for reconstruction of the edification of one of the most significant areas of the monastery, the choir loft. These documents reveal the peculiarities of this fundamental space in the jerome monks' life; which extend our information with the art presence of stained-glass windows in Aragon and bring in new data about artists enlisted to carry out the works: the sculptor Pedro Laguardia and the master glazer Francisco de Valdivieso.

Key words: Saint Engracia's Monastery, Stained-glass window, Choir, Pedro Laguardia, Francisco de Valdivieso

\footnotetext{
${ }^{1}$ Deseamos expresar nuestro más sincero agradecimiento al M. I. Sr. Don Juan Carlos Barón Aspiroz,
}

deán y canónigo archivero-bibliotecario de la Catedral de Huesca, por todas las facilidades y la amabilidad 


\section{INTRODUCCIÓN}

Desde finales del siglo XV, en la ciudad de Zaragoza se desarrolló un importante proyecto constructivo: la edificación y dotación del monasterio de Santa Engracia, una de las empresas arquitectónicas más notables y ambiciosas llevada a cabo en Aragón por estos años y a lo largo de las décadas siguientes. Un proyecto que no habría podido concretarse sin el patrocinio regio.

Tal como relata Zurita, el rey Juan II de Aragón se había recuperado de una afección de cataratas tras una intervención llevada a cabo en el palacio de la Aljafería por un rabí de Lérida, Crexcas Abiabar². El monarca atribuyó el restablecimiento de su visión a la intervención de Santa Engracia, después de haber oído misa en las gradas del altar mayor del monasterio y de haber tenido sobre sus ojos la cabeza de la santa ${ }^{3}$. En agradecimiento extendió sobre el santuario, que encomendó a la Orden Jerónima, su protección y apoyo. Sin embargo, el favor del monarca

prestadas en la consulta de los fondos del riquísimo Archivo de la catedral oscense y en el estudio in situ de la vidriera de la Ascensión de dicho Templo. Asimismo, a Cándido Puyal Sanmartín y a Yolanda Badía Gimeno, de la empresa Vitrales Huesca, por su asesoramiento técnico, por el material gráfico que nos han proporcionado y las informaciones facilitadas sobre la restauración de la misma.

2 Suceso que el Cronista sitúa en 1468 y que otras fuentes retrotraen al año 1459. C. MORTE GARCÍA, "El monasterio Jerónimo de Santa Engracia de Zaragoza en el mecenazgo real", en VV. AA., Santa Engracia. Nuevas aportaciones para la historia del monasterio y basílica, Zaragoza, 2002, p. 103 y J. CRIADO MAINAR, “La fábrica del monasterio Jerónimo de Santa Engracia de Zaragoza. 1492-1517", Artigrama, no 13, 1998, p. 254.

3 Una pieza relicario gótica, regalada por el Papa Benedicto XIII y desaparecida durante la Guerra de la Independencia. C. MORTE GARCÍA, Op. cit., p. 104. Los detalles de la mediación de la Santa y los acontecimientos posteriores son recogidos de forma pormenorizada por P. Fray L. B. MARTON, Origen, y Antiguedades de el Subterraneo, y Celeberrimo Santuario de Santa Maria de las Santas Massas, oy Real Monasterio de Santa Engracia de Zaragoza de la Orden de nuestro Padre San Geronimo, (edición facsímil), Zaragoza, 1991, pp. 475-477. no pudo concretarse durante su reinado en obras de edificación, debido a la guerra y crisis general del momento ${ }^{4}$.

Serían su hijo Fernando II el Católico y el nieto de éste, el emperador Carlos I, los que promoverían los trabajos constructivos que dieron forma material a la voluntad de su predecesor ${ }^{5}$. Sabido es que del complejo monástico solo queda en pie la extraordinaria portada. El resto de lo que fue uno de los conjuntos arquitectónicos más relevantes de Aragón ha de reconstruirse a través de los

${ }^{4}$ El Padre Sigüenza en su texto sobre el monasterio de Santa Engracia alude a la devoción de Juan II a la santa y a su curación en 1459, así como a la cesión del recinto religioso existente a la orden jerónima: “Celebrábase en aquel año [se refiere a 1459] capitulo general en la Orden de San Jerónimo, y escribió -como parece en el libro original de los actos de nuestros capitulos- una carta, rogándole a la Orden encarecidamente quisiese recibir la Iglesia de Engracia para monasterio de la Orden. La Orden se mostró agradecida a tanta merced; señaló luego dos religiosos para que fuesen a tratar con el Rey del asiento, y para que viesen la comodidad que aquella iglesia tenia..." Recogido por Fray I. de MADRID (O. S. H.), "El monasterio Jerónimo de Santa Engracia en la obra del Padre Sigüenza", Aragonia Sacra, VII-VIII, 1992-1993. Monográfico Santa Engracia, pp. 155-156.

Por su parte, Carmen Morte subraya la vinculación de la monarquía con la Orden Jerónima, privativa de la Península Ibérica. Una relación que halló su máxima expresión en época de la dinastía castellana Trastámara, que reinó en Aragón desde 1412. En el reino de Aragón no existía ningún monasterio de esta orden, por lo que la decisión de Juan II seguía a la vez una tradición y constituía un hito en los territorios aragoneses. C. MORTE GARCÍA, Op. cit., p. 104. Sí existían monasterios jerónimos en otros territorios de la Corona de Aragón: en Valencia o Barcelona, donde se fundó el Monasterio de San Jerónimo de la Vall d'Hebron, a finales del XIV o el Monasterio de San Jerónimo de Murtra, impulsado por el propio monarca Juan II.

${ }^{5}$ Una síntesis muy completa sobre la fundación del monasterio y de las gestiones diversas llevadas a cabo inicialmente por Fernando el Católico para culminar la voluntad de su progenitor puede consultarse en C. MORTE GARCÍA, Op. cit., pp. 105-107 y en el estudio que la misma autora dedica a los cantorales miniados de la orden jerónima: C. MORTE GARCÍA, "Los cantorales miniados de la orden Jerónima en el Reino de Aragón", en M. C. LACARRA DUCAY, (coord.), La miniatura y el grabado de la Baja Edad Media en los archivos españoles, Zaragoza, 2012, pp. 281-290. 
testimonios escritos, más o menos extensos ${ }^{6}$, y de las noticias documentales, sin duda exiguas, a partir de las cuales diversos historiadores han analizado hitos y realizaciones artísticas perdidos para siempre ${ }^{7}$.

Al llevarse a cabo la fundación monástica ya existía una iglesia superior, $\mathrm{cu}$ yas obras se habían desarrollado gracias al mecenazgo del alto clero, de la nobleza y de los propios creyentes. Esta iglesia alta se asentaba sobre otra subterránea, conocida como Santuario de las Santas Masas, que custodiaba las veneradas reliquias de Santa Engracia, San Lamberto y otros mártires cesaraugustanos $^{8}$. Sería a finales de 1492 cuando se produciría la fase proyectiva del conjunto monástico y se iniciarían los trabajos de edificación del recinto9. Para el

${ }^{6}$ Sin duda el más significativo es la historia del padre fray León Benito Martón, ya citada, que constituye un documento excepcionalmente rico y de consulta imprescindible. P. Fray L. B. MARTÓN, Op. cit. Otras fuentes documentales escritas son mencionadas por A. ANSÓN NAVARRO, "La iglesia alta del Real Monasterio de Santa Engracia de Zaragoza: Aproximación a un monumento desaparecido", Seminario de Arte Aragonés, números XXIX-XXX, 1979, pp. 6-7.

${ }^{7}$ Hay que resaltar por su trascendencia los estudios que sobre el monasterio se recogen en la obra conjunta titulada Santa Engracia. Nuevas aportaciones para la historia del monasterio y basílica. Además de Carmen Morte, ya citada, intervienen en esta publicación conjunta otros especialistas en Historia del Arte como Carmen Lacarra, Javier Ibáñez o el propio Arturo Ansón Navarro. VV. AA., Santa Engracia. Nuevas aportaciones para la historia del monasterio..

${ }^{8}$ Para conocer el avance de estas obras léase M.C. LACARRA, "La iglesia parroquial de Santa Engracia o Santuario de las Santas Masas durante el siglo XV, nuevas noticias", en VV. AA., Santa Engracia. Nuevas aportaciones para la historia del monasterio y basílica... pp. 83-100.

${ }^{9}$ El rey Fernando el Católico comunicaba el 5 de octubre de 1492 a su sobrino, el Obispo de Huesca Juan de Aragón y Navarra (bajo cuya jurisdicción se encontraba la iglesia de Santa Engracia, la cual, situada extramuros de la ciudad de Zaragoza, había sido donada por el obispo Paterno de Zaragoza a su homónimo oscense en el año 1062), y a los Jurados de Zaragoza la orden para iniciar la construcción del cenobio: "Por la grande deuocion que tenemos al bienauenturado Sant Geronimo, cuya orden como sabeys ha mucho floreado en nuestros Reynos de Castilla, viendo que objetivo de este trabajo resulta significativo realizar, si quiera un breve apunte, acerca de los avances llevados a cabo en la ampliación de la mencionada iglesia superior del recinto, en la que se ubicaba el coro de los monjes.

El momento clave para la culminación de las tareas de edilicia en la iglesia se produciría en el año 1511, cuando Fernando II de Aragón persuadió a la comunidad jerónima de Santa Engracia para que eligieran como prior a fray Martín de Vaca, monje profeso en el convento de Santa María de la Sisla en Toledo $^{10}$, que poseía conocimientos en ma-

en este Reyno no hay monesterio de la dicha orden y el seruicio grande que dello se spera seguir a nuestro Senyor y beneficio a esta Ciudat, mucho tiempo ha que tenemos deliberado fazer monesterio de la dicha orden la iglesia de Santa Engracia y como quiere que en dias pasados obtuuimos bulla de nuestro muy Sancto padre para fazerlo pero con las grandes ocupaciones que hauemos tenido no hauemos podido fastaqui entender en ello, agora damos orden que se laure en la casa lo que menester fuere y que vengan los religiosos a star en el y que los beneficios sean subprimidos iuxta forma de la dicha bulla". Archivo de la Corona de Aragón (en adelante ACA), Registros de Cancillería, no 3.571, fol. 33r. La prioridad dada por el monarca al proyecto edilicio queda patente al comprobar cómo al año siguiente, Fernando el Católico, en respuesta a una carta de su receptor Juan Ruíz de Bordalva en la que le mostraba sus dudas sobre la viabilidad económica del Tribunal inquisitorial ante los gastos proyectados en la edificación del complejo monástico, subrayaba "que nuestra voluntat no es en ninguna manera desfazer el officio de la Inquisicion, antes bien conseruar aquel como fastaqui se ha fecho, pero por ser esta obra de tanta deuocion y en que nos tenemos tan grande voluntat por lo mucho que nuestro Senyor sera en ello seruido, queremos y vos mandemos que por agora cesse la obra del Aljafferia e que todo lo que alli se hauia de gastar se conuierta en la dicha obra de Santa Engracia". Ibídem, fol. 73v, Barcelona, 8-V1493. Jesús Criado y Javier Ibáñez aportan más datos sobre el funcionario real Juan Ruíz de Bordalva y las obligaciones inherentes a su cargo. Véase J. CRIADO MAINAR y J. IBÁÑEZ FERNÁNDEZ, Sobre campo de azul y carmín. Programas de ornamentación arquitectónica "al romano" del Primer Renacimiento aragonés, Zaragoza, 2006, p. 19.

${ }^{10}$ Carmen Morte señala que el monarca hizo prevalecer su criterio ante el padre General de la Orden. C. MORTE GARCÍA, “El monasterio Jerónimo de Santa Engracia de Zaragoza en el mecenazgo real"... p. 124. 
teria de arquitectura y construcción ${ }^{11}$. Para garantizar el éxito de la empresa, el monarca aumentó la dotación económica asignada al monasterio en varias cantidades, durante el período en el que este religioso estuvo al frente del cenobio ${ }^{12}$. El 23 marzo de 1514 fray Martín de Vaca contrató a los hermanos Juan y Luis de Santa Cruz, residentes en Toledo, para realizar una serie de obras en la iglesia y otras dependencias del monasterio ${ }^{13}$.

Los hermanos Santa Cruz acometieron la ampliación de la iglesia que se había edificado en el siglo XV. Era un templo de una nave con una torre campanario levantada hacia 1450, que los maestros alargarían en más de un tercio por la zona de los pies. En los dos últimos tramos se levantaría la portada renacentista, las dos torres de la fachada y el coro alto ${ }^{14}$.

${ }^{11}$ Ibídem. p. 124 y J. CRIADO MAINAR, Op. cit., pp. 260-262.

${ }^{12}$ Así lo narra el Padre Martón: "Su animo fue que toda la Iglesia se renovasse, aunque preocupado de la muerte no lo pudo executar, y dize la citada Historia, que deseando fuessen muy Regios todos los Edificios de esta Casa, se interpuso con sus Monges, y nuestro Padre General; para que al Padre fray Martin Vaca hiziessen Prior, por ser habil, y entendido de Arquitecturas, y Obras. Condescendieron como era razon; siendo Professo de Toledo, en nuestro Monasterio de la Sissa; y le mandò librar el Rey treze mil Escudos, los que gastò, y aun otras cantidades, adelantando estas Magestuosas Fabricas, dentro los seis años, que hasta el de 1517 desempeñò con grande esplendor este Priorato". P. Fray L. B. MARTÓN, Op. cit., p. 503. Carmen Morte alude a ese incremento de la asignación por una cuantía de 13.000 escudos, a los que habría que añadir los 55.000 sueldos que Fernando el Católico ordenó al tesorero real Luis Sánchez que entregara al prior fray Martín de Vaca. C. MORTE GARCÍA, "Fernando el Católico y las artes", en VV. AA., Las artes en Aragón durante el reinado de Fernando el Católico (1479-1516), Zaragoza, 1993, pp. 162 y siguientes.

${ }^{13}$ La procedencia de los maestros, la misma que la del prior, parece indicar que éstos podrían haber trabajado en el monasterio toledano de la orden jerónima. C. MORTE GARCÍA, “El monasterio jerónimo de Santa Engracia..." p. 125 y J. CRIADO MAINAR, Op. cit., p. 262.

${ }^{14}$ C. MORTE GARCÍA, “El monasterio jerónimo de Santa Engracia..." pp. 125-126 y J. CRIADO MAINAR, Op. cit., pp. 262 y $273-275$.

\section{EL CORO DE LA IGLESIA ALTA}

Habilitar el coro alto fue sin duda un asunto muy importante para los monjes de Santa Engracia. Prueba de ello es que el padre Martón alude con frecuencia al espacio del coro en su historia del monasterio de Santa Engracia, apuntando características del mismo, usos y funciones, de forma muy concreta. En una de estas alusiones, el religioso da noticia de las obras de ampliación de la iglesia que permitieron el acondicionamiento del coro alto:

"Los solidos fundamentos de subsistir, han de ser todo el Coro de los Martyres... Bien lo creìa nuestro Rey Don Fernando el Catholico, quando para agradezer tan grandes beneficios, desde los Cimientos este coro hizo labrar, donde à Dios se repitiessen sus Alabanzas... Probò esta Historia no llegava la Iglesia de sobre nuestras Cryptas, sino hasta la Torre de las Campanas, y la que està por subir junto al Organo; pero ahora se dilatò àzia el Septentrion mas de una terzera parte, siendo donde registramos el Coro, y con dos Torreones su celebre Portada..."15.

Las actuaciones que habían de llevarse a cabo en el coro quedaron en parte recogidas en un documento, redactado en 1513 por el prior del monasterio, a petición del rey Fernando de Aragón. En este memorial se hablaba del comienzo de la labra de la sillería del coro, con una mención particular a la silla del prior y al facistol de nogal. Además, se señalaba la necesidad de realizar seis vidrieras grandes para la iglesia, semejantes a las del refectorio, que supondrían un desembolso de 50 ducados cada una; un óculo con su guarnición de hierro, para el que se preveía un gasto de 100 ducados y las filacterias o claves doradas para las bóvedas, por una suma total de 200 ducados $^{16}$.

\footnotetext{
${ }^{15}$ P. Fray L. B. MARTÓN, Op. cit., p. 502.

16 "Memorial que mandó hazer Su Alteza al prior de santa Engracia para lo que es menester para labrar y acabar la casa que Su Alteza haze de santa Engracia". El contenido de este memorial puede consultarse en C. MORTE GAR-
} 
En el acuerdo suscrito el día 23 de marzo de 1514 entre el prior fray Martín de Vaca y los hermanos Juan y Luis de Santa Cruz, se expresaba que ambos maestros debían abordar, entre otros trabajos, algunas tareas que afectaban de forma expresa a la zona del coro: realizar las bóvedas de crucería que cubrirían el mismo, así como las bóvedas del sotocoro, también de crucería, y abrir ventanas en este tramo y en los demás correspondientes a la ampliación de la iglesia. Por otro lado, se contemplaba la ejecución de una serie de labores decorativas de yeso en las repisas en las que apoyaban los nervios de las bóvedas de crucería estrellada, donde habían de situarse dos ángeles sosteniendo las armas reales y un letrero con un texto que no se detalla ${ }^{17}$.

Nada se decía en ese contrato del cierre de las ventanas con vidrieras, ni de las filacterias y claves de las bóvedas para los que se habían consignado las correspondientes partidas económicas en el Memorial del año 1513. ¿Se llegaron a hacer? Y, si así fue, ¿quién y cuándo las emprendió y ultimó? Los hallazgos documentales que aquí se presentan permiten responder a estos interrogantes.

El día 13 de julio de 1515 en la ciudad de Zaragoza y ante el notario Alfonso Francés, se firmaba una capitulación entre el prior del monasterio de Santa Engracia, fray Martín de Vaca, llamado en el contrato "fray Martin de La Sisla", y el vidriero Francisco de Valdivieso, vecino de Burgos, residente en esa fecha en la capital aragonesa, en virtud de la cual el segundo se comprometía a realizar tres vidrieras para las ventanas del coro. Una de ellas había de cerrar el óculo "la o del coro" y debía de representar "un crucifixo con Sant Johan y Nuestra Senyora a los lados y al pie ha de star la Magdalena". Otra vidriera debía dedicarse a San Jerónimo y la

CÍA, "Los cantorales miniados de la orden Jerónima en el Reino de Aragón...", pp. 288-289.

${ }^{17}$ C. MORTE GARCÍA, "El monasterio jerónimo de Santa Engracia..." p. 125 y J. CRIADO MAINAR, Op. cit., pp. 273-275. última a Santa Engracia, San Lamberto y los "XVIII cavalleros". En estas dos últimas el vidriero había de componer las armas reales. Las vidrieras debían de estar acabadas y asentadas en los vanos correspondientes en la Navidad de ese mismo año. Por el trabajo, incluidos los materiales necesarios, con excepción de las guarniciones y redes de hierro para la protección de los vidrios, el artífice recibiría un pago de 50 ducados, siempre que el resultado final demostrase que valía el precio acordado (Apéndice documental, doc. $\left.\mathrm{n}^{\mathrm{o}} 1\right)^{18}$.

Los pagos, como era usual en este tipo de contratos, se fraccionaron en tres tandas: una al comienzo de las obras, de forma que el maestro vidriero pudiera disponer de un capital suficiente para adquirir los materiales y hacer frente a otros gastos; una segunda entrega a mitad del período y el resto cuando la obra se hubiera terminado. Pero, si la misma no se había finalizado en el tiempo estipulado, Francisco de Valdivieso sería penalizado con 10 ducados de multa.

El contrato dejaba a Francisco de Valdivieso a merced del criterio del prior y de Felipe Ortal ${ }^{19}$, con la posibilidad de percibir unos emolumentos menores en caso de que ambos no quedaran satisfechos, y con poco margen de ganancias en caso de que la obra

${ }^{18}$ Pascual Galindo Romeo tuvo acceso a este documento y dio una breve noticia de su contenido en la revista El Pilar del año 1920. Sin embargo, señala equivocadamente que fue el arzobispo don Alonso de Aragón el que contrató al vidriero Francisco de Valdivieso para llevar a cabo estas vidrieras. P. GALINDO ROMEO, “1520-1920. Centenario de un gran Arzobispo. IV D. Alonso, mecenas de la Seu”, El Pilar, no 1905, 13 de marzo de 1920, pp. 82-83. Este número de la revista El Pilar ya había sido localizado por Javier Ibáñez Fernández. J. IBÁÑEZ FERNÁNDEZ, "La portada de Santa Engracia", en VV. AA., Santa Engracia. Nuevas aportaciones para la historia del monasterio y basílica... p. 204.

${ }^{19}$ Es posible que este Felipe Ortal sea el el titular de una capilla de patronato laical que se encontraba en la iglesia alta del Monasterio de Santa Engracia. Sin embargo, no poseemos más datos al respecto. Véase la nota 26 , donde se mencionan ésta y otras capillas del mismo carácter. 
resultase de mayor calidad y precio que el previsto inicialmente. Cabe recordar, por otro lado, que en el Memorial de 1513, realizado por el prior como respuesta al mandato de Fernando el Católico, se preveía un gasto de 50 ducados por vidriera y de 100 ducados para el ojo u óculo, una estimación muy por encima del precio final de la obra.

Unos meses después, el 24 de septiembre de 1515, el mismo prior de Santa Engracia firmó un contrato con el escultor Pedro Laguardia para ejecutar otra de las empresas artísticas previstas en el Memorial de 1513, las filacterias y claves de las bóvedas. En concreto, el artista había de realizar "las filaterias del coro altas e vaxas de follages del romano, segunt esta en la muestra que fizo", además de varias claves de bóvedas para cuya ejecución el prior debía de proporcionarle la madera necesaria. Los pagos se abonarían al terminar la obra (Apéndice documental, doc. $\mathrm{n}^{\mathrm{o}}$ 2).

En realidad, éste era el segundo contrato que Pedro Laguardia suscribía con el prior Martín de Vaca, pues el mismo día ambos habían acordado que el escultor tallase un crucifijo de madera de nogal de ocho palmos. Se especificaba en el documento que la obra debía de ser de gran calidad y aprobada por el prior, o bien tasada por dos maestros si el religioso no estaba conforme con el resultado. La tasación no podría superar los 200 sueldos, como precio final y se haría, si fuera necesario, al finalizar la obra "fasta Pascua Florida que viene" (Apéndice documental, doc. $n^{\mathrm{o}}$ 3).

Por otro lado, hay que indicar que en estas dos capitulaciones suscritas con Pedro Laguardia firmaron como testigos Juan Santa Cruz, uno de los hermanos venidos de Toledo que estaban al frente de los trabajos de edificación en el cenobio jerónimo, circunstancia ya indicada en las líneas precedentes, y el pintor Jaime Serrat. Éste último había sido pintor de confianza del rey Fernando de Aragón y recomendado por el monarca en 1492 a los jurados de la ciudad de Zaragoza, por ser artífice de gran habilidad. No fue ésta la única vez en la que el monarca avaló las dotes artísticas de Serrat, pues en el año 1514 habló en su favor al cabildo de Cartagena para la hechura del retablo mayor de la catedral. Fue nombrado en 1487 pintor de la casa del príncipe Juan y estuvo al servicio de don Alonso de Aragón, arzobispo cesaraugustano, hijo del propio rey católico. El testimonio de Jaime Serrat en las capitulaciones reseñadas nos habla de una posible relación profesional con Pedro Laguardia o tal vez de la participación del artista del pincel en obras de su competencia en el monasterio de Santa Engracia $^{20}$.

Además, todos estos contratos nos proporcionan datos acerca de las características de las obras acordadas, pero también nos revelan el nombre de los artistas que las acometieron, permitiendo sumar así nuevos trabajos y responsabilidades artísticas a las que hasta ahora se les atribuían.

Pedro Laguardia es conocido sobre todo por las obras realizadas en el cimborrio de La Seo de Zaragoza. En los años 1520 y 1521 se encargó de la labra de las ocho esculturas de yeso de los Evangelistas y Padres de la Iglesia latina que habían de ocupar las hornacinas del primer nivel del tambor, y también de la realización del letrero de madera que separa el primer cuerpo del segundo ${ }^{21}$. Intervino también en la ornamentación de la capilla de Santiago de la catedral cesaraugustana, hoy desaparecida. En el contrato, fechado en julio de 1521, se obliga Laguardia a realizar una serie de labores ornamentales, de follaje y coronas, en la parte superior y muros de dicha capilla, así como otras deco-

\footnotetext{
${ }^{20}$ Carmen Morte sintetiza la información que poseemos acerca de Jaime Serrat, extraída por diversos autores de las fuentes documentales, pues no se conocen obras suyas. C. MORTE GARCÍA, "Fernando el Católico y las artes...", p. 167.

${ }^{21}$ J. IBÁÑEZ FERNÁNDEZ, Arquitectura aragonesa del siglo XVI. Propuestas de renovación en tiempos de Hernando de Aragón (1539-1575), Zaragoza, 2005, p. 203, especialmente nota no 282; ÍDEM, Los cimborrios aragoneses del siglo XVI, Tarazona, 2006, p. 13.
} 
raciones semejantes en la portada ${ }^{22}$. Además, se expresa que esta decoración ha de ser semejante "como sta en Santa Engracia en la capilla de Felipe de Ortal y los fullajes de la misma labor y orden que alli stan", lo que permite apuntar la posible intervención del propio Pedro Laguardia en esta capilla del monasterio cesaraugustano.

Laguardia fue el encargado de llevar a cabo la sillería de coro del monasterio de San Victorián, como se deduce del albarán de quince libras que el artista firmó el 21 de septiembre de 1521 a favor del reverendo García Pascual, prior de la villa de Graus y vicario general del abadiado de San Victorián. En este documento aparece como testigo Juan de Oñate, discípulo de Pedro Laguardia, con el que se firmó como aprendiz el día 15 de junio de $1517^{23}$.

También es posible que realizase la mazonería del retablo de la capilla del Patrocinio de Daroca, habida cuenta de la existencia de una capitulación, firmada entre el artista y Aznar Ruíz de Senés en el año 1515. No obstante, la desaparición de parte del protocolo notarial, no permite sino especular en este sentido ${ }^{24}$. Laguardia realizó otros retablos, uno para Juan de Bolas, contratado en diciembre del año $1524^{25}$, y el que resulta más interesante en el presente contexto, que se encontraba en la capilla del vicecanciller del Rey, Antonio Agustín, en el propio monasterio de Santa Engracia, cuyo asentamiento se acordó en el año 1524 (Apéndice documental, doc. $\mathrm{n}^{\mathrm{o}} \mathrm{4}$ ). Esta capilla fue dona-

${ }^{22}$ M. ABIZANDA BROTO, Documentos para la historia artística y literaria de Aragón procedentes del Archivo de protocolos de Zaragoza. Siglo XVI, Tomo I, Zaragoza, 1915, pp. 123-124.

${ }^{23}$ Ibídem, pp. 246 y 248-249.

${ }^{24}$ M. L. MIÑANA, RODRIGO, F. SARRÍA ABADÍA, R. SERRANO GRACIA, R. CALVO ESTEBAN, A. HENÁNSANZ MERLO, M. D. PÉREZ GONZÁLEZ y F. MAÑAS BALLESTÍN, "La capilla del Patrocinio de la iglesia colegial de Daroca: datos documentales", Actas del V Coloquio de Arte Aragonés, Zaragoza, 1989, p. 193.

${ }^{25}$ M. ABIZANDA BROTO, Op. cit., Tomo II, pp. 249-250. da el 15 de septiembre de 1518 al matrimonio formado por Antonio Agustín y Aldonza Albanell (Apéndice documental, doc. $n^{\mathbf{0}} 5$ ) $^{26}$ y es descrita por el Padre Martón, subrayando el elevado coste de los trabajos artísticos realizados en la misma, singularmente en el sepulcro de alabastro ${ }^{27}$.

Del carácter de estas obras encomendadas a Laguardia cabe deducir que era éste un escultor especializado en trabajos de madera y yeso. Su quehacer en las filacterias del coro alto y sotocoro del monasterio de

${ }^{26}$ El documento de donación, al especificar la ubicación de dicha capilla junto al presbiterio mayor y el perímetro de la misma, aporta importantes datos para el conocimiento del espacio interno de la iglesia del complejo monástico, así como para determinar los nombres de otros titulares de capillas de patronato laical enterrados en dicha iglesia, como Luis González o Felipe Ortal. Como ya se ha apostillado en la nota 19, en el momento actual no podemos precisar con total exactitud la vinculación de Felipe Ortal con el monasterio de Santa Engracia. Tampoco es posible afirmar que el Felipe Ortal titular de la capilla mencionada sea el mismo que el citado en el contrato firmado con el maestro vidriero Francisco de Valdivieso como responsable, junto al prior Martín de Vaca, de la tasación de las vidrieras ejecutadas por el mencionado maestro.

27 "La primera por la yzquierda del dicho Altar Mayor, es Capilla de nuestro Padre San Geronimo, erigiendola costosissima por aquel tiempo, el Vicecanciller de Aragon Don Antonio Agustin... Muy devido por sus Empleos tan sobresalientes, los que recordarán las memorias de su Epitaphio... Padre del Doctor D. Pedro Agustin, Obispo de Huesca, y de Don Antonio Agustin, Arzobispo de Tarragona, aquella Lumbrera del Derecho Canonico, y Antiguedades, ò Erudicion de Divinas, y humanas Letras, que con razon tanto el Orbe Christiano proclama. Dieronle dicha Capilla al moverles la gratitud, de lo que nos favoreciò en la pretension de Exea, influyendo se uniesse su Priorato à estas Cryptas; y para que roguemos à Dios por su Alma, la Historia manuscrita lo previene. Està à la mano derecha su celebre Sepulcro de Alabastro, con dos Columnas de orden Corinto, adornado de varias Efigies de las Virtudes, y debaxo la Urna en que yàze sepultado, con su Efigie encima de medio Relieve; y que la sostienen Carteloncillos agradables, por la variedad de sus entalladas molduras. Frontero gravado su Epitaphio se registra en doze lineas Latinas, que nos recuerdan aver sido Vicecanciller, y Consejero de Don Fernando el Catholico, y Carlos Quinto, Embaxador al Rey de Francia, y al Papa Julio Segundo; falleciendo à 28 de Marzo del año 1523". P. Fray L. B. MARTÓN, Op. cit., pp. 709-710. 
Santa Engracia no sería muy diferente del tipo de labor que realizó años después en el letrero del cimborrio de la metropolitana de Zaragoza, en la capilla de Santiago de la propia catedral y posiblemente en la capilla de Felipe de Ortal, también en el monasterio jerónimo. No resultaría muy aventurado suponer que la calidad del trabajo que realizó en el coro de Santa Engracia pudo influir en su designación para acometer otros de naturaleza similar a los aquí apuntados. Y es aún menos atrevido afirmar que el trabajo en el coro del monasterio fue determinante a la hora de escogerle para llevar a cabo el retablo de la capilla del vicecanciller Antón Agustín en 1524.

Por su parte, Francisco de Valdivieso era hijo del maestro vidriero burgalés Juan de Valdivieso que formó parte de la generación de vidrieros, junto a Arnao de Flandes y Diego de Santillana, que constituyeron la avanzada de una nueva corriente en este campo artístico. Gracias al carácter itinerante de su trabajo, fueron difundiendo las nuevas formas renacentistas por la Península Ibérica. Los tres ejercieron un verdadero monopolio del arte de la vidriera en Castilla desde finales del siglo XV. Realizaron vidrieras en Burgos, Palencia, Ávila, León, Santiago de Compostela y Salamanca ${ }^{28}$. Diego de Santillana, en concreto, fue el autor de las excepcionales vidrieras de la capilla de Santiago de la catedral de León, así como de otros ventanales ejecutados en el Hospital Real de Santiago de Compostela, en la ca-

${ }^{28} \mathrm{~V}$. NIETO ALCAIDE, La vidriera española. Ocho siglos de luz, Madrid, 1998, pp. 131-133 y 137-141. Resulta imposible realizar aquí una nómina detallada de todos los trabajos realizados por estos artífices del vidrio. Tan solo se mencionará, además de las referencias apuntadas, alguna intervención especialmente sobresaliente, como la realizada por Juan de Valdivieso y Arnao de Flandes en la vidriera de La Adoración de los Reyes para la Capilla del Cardenal en la catedral abulense. Esta obra, que el citado autor considera una de los ejemplos más sobresalientes de la vidriera española de finales del siglo XV, fue contratada en mayo de 1498 , junto con otras dos vidrieras que los maestros se comprometieron a ejecutar para dicha capilla. V. NIETO ALCAIDE, La vidriera del Renacimiento en España, Madrid, 1970, pp. 18-19. tedral de Ávila, en la de Oviedo o en la de Palencia, ciudad en la que trabajó también en la iglesia de San Francisco. La presencia en Aragón de Francisco de Valdivieso supuso la llegada de esas formas renacentistas a las vidrieras realizadas en este período en el Reino, siguiendo la estela iniciada por su padre y sus colegas en Castilla. Su contratación vendría determinada por el deseo de contar con un maestro de experiencia y prestigio en el campo. Diversas fuentes han señalado que Francisco Valdivieso residía en Huesca en el año 1510. Tal afirmación parte del documento firmado por el artista para realizar una vidriera en la capilla del Gran Canciller de Aragón en época de Carlos I, Jean de Sauvage, transcrito por Manuel Abizanda y fechado erróneamente en ese año. En realidad, dicho contrato no se firmó hasta el año 1519, por lo que es posible que la llegada de Francisco de Valdivieso a tierras aragonesas coincidiese con el encargo de realizar las vidrieras del coro de Santa Engracia ${ }^{29}$. Entre 1516 y 1519 abordó la ejecución de nuevas vidrieras para la catedral de Huesca, en su mayor parte perdidas. Ricardo del Arco recoge una serie de asientos de los Libros de Fábrica de la seo oscense, en los que se anotaron los pagos realizados a Francisco de Valdivieso por hacer las vidrieras para el rosetón situado enci-

\footnotetext{
${ }^{29}$ Así lo hace, por ejemplo Ricardo del Arco, quien señala, además, que su fuente es Abizanda. R. del ARCO, La catedral de Huesca. (Monográfico histórico arqueológico), Huesca,1924. Manuel Abizanda publicó el contrato suscrito entre el prior del monasterio de Santa Engracia y el maestro vidriero Francisco de Valdivieso para realizar la vidriera de la capilla del Canciller Sauvage, pero lo fechó el 12 de enero de 1510. Esta fecha resulta, de entrada, difícil de comprender, habida cuenta que el Gran Canciller falleció en el año 1518 y de que es a partir de este año cuando se han datado las obras realizadas en su capilla de la iglesia de Santa Engracia. M. ABIZANDA BROTO, Op. cit., Tomo II, p. 399. Así, fue en 1518 cuando el propio Abizanda documentó el contrato firmado con el escultor Alonso Berruguete para realizar el sepulcro de dicha capilla. Ibídem, p. 254. La revisión de la documentación del Archivo de Protocolos Notariales de Zaragoza revela que el acuerdo suscrito con Francisco de Valdivieso se firmó en el año 1519, y no en 1510. Archivo Histórico de Protocolos Zaragoza (en adelante AHPZ), Notario Miguel de Villanueva, 1519, fols. 28r-29r.
} 
ma de la portada de la iglesia, así como otros cerramientos destinados a las capillas de San Nicolás, Nuestra Señora, San Pedro y Santa Catalina. Finalmente, en otros apuntes se menciona la colocación, por parte del maestro, de vidrieras en las ventanas situadas en la zona del órgano y, ya en 1518, la hechura de otras vidrieras ubicadas en el crucero ${ }^{30}$.

Por último, cabe recordar que en 1519 fue contratado para hacer la vidriera de la capilla de Jean de Sauvage o Selvagio, que falleció en la capital aragonesa, ubicada también en el monasterio de Santa Engracia ${ }^{31}$.

\section{EL CORO ALTO DEL MONASTERIO DE SANTA ENGRACIA. IMPORTAN- CIA LITÚRGICA}

Parece que el coro de la iglesia monástica estaría concluido en 1518. Cuenta Jesús Criado, tomando como fuente la Crónica de los Reyes Católicos de A. Santa Cruz, que la sillería y la portada debieron instalarse en 1517, de manera que en 1518, cuando Carlos $\mathrm{V}$ visitó el recinto durante su estancia en Zaragoza para jurar los fueros, los vio termi$\operatorname{nados}^{32}$.

Era el coro de Santa Engracia un espacio situado en alto, a los pies de la iglesia. Se elevaba, como hemos visto, sobre una bóveda de crucería realizada por los hermanos Santa Cruz y se cubría con bóvedas también de crucería $^{33}$, todas ellas ornadas con las claves doradas realizadas en 1515 por Pedro Laguardia y a las que el padre Martón hace

${ }^{30}$ R. del ARCO, Op. cit., p. 81. La relación de pagos realizados a Francisco de Valdivieso y a otros artífices que colaboraron en la ejecución de las vidrieras de la catedral de Huesca, ha sido también recogida por Antonio Durán Gudiol en su monografía sobre la mencionada catedral. A. DURÁN GUDIOL, Historia de la catedral de Huesca, Huesca, 1991, p. 139. 28r-29r.

${ }^{31}$ AHPZ, Notario Miguel de Villanueva, 1519, fols.

${ }^{32}$ J. CRIADO MAINAR, Op. cit., p. 265.

${ }^{33}$ C. MORTE GARCÍA, "El monasterio jerónimo de Santa Engracia...", p. 125 y J. CRIADO MAINAR, Op. cit., pp. 273-275. referencia en varias ocasiones ${ }^{34}$. Las dimensiones de este coro, según el testimonio del propio padre Martón, eran de noventa y seis palmos de largo y setenta de ancho, coincidiendo con la anchura de la propia iglesia ${ }^{35}$.

Al ubicar el coro en posición elevada se siguió en la iglesia de Santa Engracia una práctica común en la orden jerónima. $Y$, aunque tal ubicación no fue ideada por esta orden, ya que es habitual en otras iglesias monásticas, conventuales o parroquiales del período, sí fue una opción siempre escogida por los jerónimos, que llegó a convertirse en un rasgo distintivo de sus templos. Así cabe deducirlo de las palabras de Antonio Ponz quien, al visitar la iglesia de San Miguel de los Reyes (Valencia), señalaba que el coro de la misma estaba en la entrada como es uso en los conventos de la orden. Y con anterioridad Jerónimo Münzer, en 1495, durante su estancia en el monasterio de Guadalupe, también hace referencia a esta costumbre con unas palabras que permiten entender que tal preferencia vino motivada por su idoneidad litúrgica: "Frente al coro está el altar mayor, levantando trece escalones sobre los demás; de esta manera, los padres pueden ver cómodamente los misterios de la misa desde el coro alto posterior" ${ }^{\prime 36}$. Una liturgia que en

\footnotetext{
${ }^{34}$ En concreto, Martón subraya que "la Favrica es de una Nave, toda de Arquitectura Gotica, con sus Bovedas de cruceria, como las Capillas, y debaxo el Coro; moteados por lo que Rampante dize, y llevan las Claves Rosetones dorados". P. Fray L. B. MARTÓN, Op. cit., p. 707. Las claves de las bóvedas del coro, así como las de la sacristía, y las de las tres escaleras que dan acceso al claustro alto, la de la Enfermería, Ropería y Principal, se habrían dorado, según el testimonio del padre Palayn, recogido a su vez por Martón, con oro procedente de América: “...notando el P. Palayn, fue de el primer Oro, por orden de el Sr. Fundador, el Rey D. Fernando, que Colon trajo de la America, ò Indias, y tambien los Rosetones de el Coro, debaxo su arco, y Sacristia, que vimos". Ibídem, p. 732.

${ }^{35}$ Ibídem, p. 711.

${ }^{36}$ J. A. RUIZ HERNANDO, "El monasterio del Escorial y la arquitectura jerónima", en F. J. CAMPOS Y FERNÁNDEZ DE SEVILLA, (coord.), El monasterio del Escorial y la arquitectura, Madrid, 2002, p. 248. Ruiz Hernando apostilla al respecto que cuando Guadalupe,
} 
la orden jerónima se cuidaba al máximo y que atrajo a un creciente número de fieles, como el propio padre Martón anota en su historia del monasterio de Santa Engracia, enfatizando la admiración que provocaba la uniformidad de los cantos, de forma que "... si el dia es solemne entran à preguntar por la festividad, ò Santo que celebramos, y es la Gracia que Dios dà à nuestra Orden: porque lo han admirado en dias muy comunes". Unos oficios corales que, a decir de Martón, arrebataban a la feligresía zaragozana ${ }^{37}$.

A estos fieles que asistían a la celebración se les reservó la nave de la iglesia, al tiempo que los monjes se acomodaron en el coro elevado. La comunidad compartía el templo con los seglares, pero se separaba física y visualmente de ellos, en un espacio acotado, cuya disposición era idónea para seguir el discurrir de la ceremonia en la capilla mayor ${ }^{38}$.

Así, para que el altar mayor fuera visible desde la silla prioral, en los monasterios jerónimos se asentó dicho altar y el presbiterio sobre una suerte de meseta a la que se ascendía por unas escaleras. Se buscaba una cierta nivelación entre el coro y la capilla mayor, los dos centros de mayor interés de la iglesia, de forma que los monjes podían seguir el culto de manera óptima. Por otro lado, la posición elevada del presbiterio y la capilla mayor, posibilitaba que los fieles hicieran lo propio, desde los bancos situados en la nave de la iglesia, en un nivel más bajo.

importante centro mariano, fue entregado en 1389 a los jerónimos, éstos no dudaron en adoptar las disposiciones oportunas para ubicar el coro a los pies, para acomodarlo a la función litúrgica que cumple en la orden, sin dejarse amilanar por las dificultades estructurales que tal decisión entrañaba.

\footnotetext{
${ }^{37}$ P. Fray L. B. MARTÓN, Op. cit., p. 223.

${ }^{38}$ En el Capítulo General de 1510 quedó establecido el uso de los espacios de la iglesia de forma explícita, sin que los fieles y los monjes pudieran mezclarse. Así, "se mando que quando los frayles salen con las gracias del refitorio suban al coro y los viejos y enfermos se puedan quedar abaxo en la iglesia mas si en la iglesia oviere seglares que tambien suban al coro con los otros". Ibídem, pp. 272 y 277.
}

Las gradas que permitían el acceso al altar podían llegar a ser muy suntuosas y destacadas $^{39}$. En el caso de la iglesia del monasterio de Santa Engracia, también el altar se disponía en una posición alta y al mismo se accedía por ocho escalones desde el presbiterio, que a su vez se alzaba sobre la iglesia gracias a otros cuatro peldaños: "Se dexan vèr por cada lado siete Capillas, con todo su Pavimento, ò piso muy llanos, hasta llegar à la Rexa de dicho Presbyterio, que à este se sube por quatro Gradas, y de su plano al mismo Altar Mayor, por ocho espaciosas, y de Azulejos admirables" ${ }^{40}$.

Espacio reservado a los monjes, y también epicentro de la vida de la orden, el coro fue un ámbito importante en los templos jerónimos. Algunos cronistas de la orden no dejan de señalar esta circunstancia y en el caso concreto del monasterio de Santa Engracia de Zaragoza, el padre Martón no es una excepción. Sus referencias al coro y al uso que del mismo hacen los monjes, son constantes en la historia que dedica al monasterio cesaraugustano. Para Martón, el coro "sobresale entre quanto tiene esta Iglesia", pues no en vano es allí "donde gastamos la mayor parte de la Vida" ${ }^{41}$.

${ }^{39} \mathrm{~J}$. A. RUIZ HERNANDO, El Monasterio de Nuestra Señora de Prado, Valladolid, 1995, p. 287.

${ }^{40}$ P. Fray L. B. MARTÓN, Op. cit., p. 707.

${ }^{41}$ Ibídem, p. 711. Esta última afirmación parece tomada literalmente del padre fray José de Sigüenza quien, al hablar del coro de la iglesia del Monasterio de El Escorial, resalta que es en él "donde gastamos la mayor y mejor de nuestra vida". P. Fray J. SIGÜENZA, La fundación del monasterio de El Escorial, Madrid, 1988, p. 318. No es posible incluir todas las referencias que el padre Martón dedica a la vida coral. Se extractan aquí solo algunas de ellas: “...congregandose, conforme explica mi Geronimo, las diversas vozes de los Monges, à solemnizar su Instituto de Canticos, ò Divinas Alabanzas". El religioso, citando la autoridad del santo fundador, enfatiza el papel del Coro en los monasterios de la orden: "Me lo confirma el Santo comentado à Jeremìas, al dezir te edificaré, esto es, en la Iglesia, para que cante al Señor como aora en este Coro: Aedificabo te, intelligamus in Ecclesia, ut cana Domino in Choro". Incluso resultan más explícitas las siguientes palabras que redundan en la misma idea y subrayan que el principal cometido de los jerónimos es el desarrollo adecuado de 
El oficio divino se centraba en el rezo de las ocho horas canónicas: maitines, laudes, prima, tercia, sexta, nona, vísperas y completas y su correcta ejecución era un asunto de máxima importancia ${ }^{42}$. Una de las cuestiones en las que pone mayor énfasis es en el estado espiritual con el que los monjes han de celebrar los divinos oficios. Así, señala que en el coro no está permitido hablar, a no ser por una necesidad urgente, o que cuando se llama a maitines todos los monjes han de levantarse con la primera señal, sin mostrar pereza y acudiendo con presteza, conocimiento pleno y libres de culpa ${ }^{43}$.

En suma, se trata de afrontar la vida coral con recogimiento, humildad y alegría, pues de otra manera, la dureza del transcurrir diario de los oficios, resultaría terrible ${ }^{44}$.

las funciones del coro: "Seràn muy agradables, enseña nuestro Santo, quando diversas vozes con uniformidad se junten, y formen un Choro, que el Señor lo reconozca suyo: Diversae voces, cum simul fuerint congregatae, Chorum Domini effitiunt. Todo lo consiguiò nuestro Maximo Patriarcha, dexando por principal Instituto de su Orden el Choro, y alavanzas Divinas de dia, y de noche; ocupacion Angelica en que tanto ha florecido, como lo acredita qualquiera de sus Monasterios". P. Fray L. B. MARTÓN, Op. cit., pp. 213-214, 502-503 y 711 y 502-503.

${ }^{42}$ Martón habla de la antigüedad de las Horas Canonicas. Las figuras de Adán, que escribió salmos, Abel, Moisés, y especialmente David, "el qual siete vezes al dia alabava à Dios", son mencionadas como prueba. Pero, aún va más allá al señalar que el origen de las alabanzas al Creador se ha de llevar al propio cielo, donde según San Ambrosio y S. Agustín, los querubines y serafines están alabando a Dios. Ibídem, pp. 213 y 256-257. Martón cita también, en su cerrada defensa de la trascendencia de los oficios corales, a San Pablo, que instó a los Confesores a que alabaran a Dios con salmos, himnos y cánticos espirituales, o a Dionisio Areopagita.

43 "porque el hombre inconsiderado, no percibe lo que trasciende à las cosas Divinas. Para esto en la puerta del Choro està puesta el agua bendita, despertadora del conocimiento, y que limpia las culpas leves con otros favores, pues en lugar tan Santo no ha de entrar inmundo, ò cosa comun, según dize la Escritura". Ibídem, pp. 216 y 733. El comentario que hace de las horas canónicas es muy prolijo. Alude de forma expresa al oficio de maitines, laudes, prima y vísperas. Ibídem, pp. 213-214, 216, 219-220.

44 "quien à la media noche està tres horas, casi lo mas del año, cantando, ò rezando con los labios solos
Y es que al padre Martón no se le escapa el rigor de la vida coral, que parecerá, en su opinión, "de asperezas intolerables...a los hombres terrenos, y tan entregados à la sensualidad, que no saben vivir sino en sus deleytes, como Brutos asquerosos en la tierra", pero que, sin embargo, produce regocijo y paz a los que la practican; abre el camino de la vida eterna y resulta un arma fundamental contra los enemigos de la $\mathrm{fe}^{45}$.

$Y$ teniendo tan repetidas alusiones al tema en la obra del Padre Martón, no resulta extraña la pormenorizada descripción que de este recinto se encuentra en la historia del cenobio cesaraugustano. $Y$ en este sentido hemos de felicitarnos, pues tan minuciosa atención ratifica en algunos puntos el contenido de la propia documentación y, en definitiva, nos aporta una imagen detallada de un ámbito arquitectónico desaparecido. Así, no solo conocemos las dimensiones del coro, ya mencionadas más arriba, sino también las características de la sillería gótica de roble de Flandes o del facistol ${ }^{46}$.

de pie, el Alma sin gusto, agena de sentir lo que trata; y otras cinco, ò seis horas entre dia; que tormento serà para el cuytado del cuerpo...". Ibídem, p. 219.

${ }^{45}$ Las palabras del religioso sobre este particular resultan explícitas: "serà Espada tan eficàz, el culto de la Alabanza Divina, qual aqui matar los Enemigos; y en el Cielo hazernos patentes, ò abrir los Reynos de la Gloria...". Ibídem, pp. 256 y 258.

46 "Se compone de dos ordenes de Sillas, altas, y baxas, como los demas Coros; pero aquí ay noventa y nueve, todas de muy vistoso Robre de Flandes, entalladas de orden Gotico, con tal primor, que encima de cada Silla de las altas, su Coronacion, ò Caparazones fingen gentilissima Boveda de Cruceria; por el espaldar un Santo de medio Relieve, ornateado todo de tan raros follages, que se dexan vèr admirables entalladuras. Sobrepuja el remate de la Silla Prioral à las otras quinze pies, prosigue dicho Martinez, adornado à mil maravillas de Piramides fuertes, y tan primorosas, que parecen de Filigrana. Las Sillas baxas sirven à las altas de Atril, sin que les falte Estatuas, y Figuras por repisa; y à los espaldares de medio Relieve alternados varios Reales Escudos, y muchos Angeles". Sobre el facistol señala: "al qual sostiene un pie triangular ornateado sobre tres Leones, en que estriva de Estatuas, ò Angelotes diferentes, y varias Figuras de medio cuerpo, rematando con su moldura entallada ayrosos, y perfectos Serafines. Se 
$\mathrm{Y}$ todas estas obras, imprescincibles para el adecuado desarrollo de los cantos corales, se situaban en un recinto elevado, alegre y bien iluminado, lo cual no solo facilitaba la adecuada lectura de los cantorales, sino que aliviaba la dureza de la vida coral, que tantas horas ocupaba a los monges en su quehacer diario. Estas "luces" o ventanas son mencionadas con detalle por el padre Marton, que alude de forma especial a la "crecida Ventana circular, con Cornisamento agraciado que la ciñe, y está sobre la dicha Silla del Prior", así como a las otras "quatro Ventanas quadradas, según el P. Fr. Braulio Martinez, altas quinze pies, y cinco de ancho, con sus historiadas Vidrieras" ${ }^{\prime 4}$. Una ventana circular que sabemos, gracias al contrato firmado en el año 1515 entre el prior de Santa Engracia y el vidriero Francisco de Valdivieso, estaba cerrada con una vidriera en la que se representaba a Cristo Crucificado con la Virgen y San Juan a los lados y María Magdalena a los pies. Con respecto a las otras cuatro ventanas de las que habla Martón, en el mismo documento notarial se especifica la realización por parte de Francisco de Valdivieso, de dos vidrieras ornadas una de ellas con la figura de San Jerónimo y sus frailes, así como con las armas reales, y la otra con las imágenes de Santa Engracia, los Innumerables Mártires y San Lamberto en sus tabernáculos, con las mismas armas heráldicas.

Este coro se mantuvo en pie hasta el siglo XVIII, sin embargo, en 1754 su estado era ruinoso, lo cual afectaba al desarrollo de los oficios y al de la liturgia en general. Así lo

subsigue una quadrada Figura, muy espaciosa para sostener los Libros, cargando sobre todos su Cornisilla, que corresponde à las quatro frentes, y à su cerramiento tres Figuras adornan, à mas de una Estatua por cada angulo. Prosigue à todo lo referido su Peana, ò Urna, con quatro Columnitas, Pedestrales, y Cornisaménto, encerrando en sí bien agraciada Nuestra Señora; y por remate un devoto Crucifixo, que lleva rematillos à las quatro esquinas", Ibídem, pp. 711-712. La sillería de coro gótica fue labrada por el fustero Juan Ximénez y el imaginero Juan de Salazar a partir del año 1512. C. MORTE GARCÍA, "Los cantorales miniados de la orden Jerónima en el Reino de Aragón...”, p. 293.

$$
{ }^{47} \text { Ibídem, p. } 711 .
$$

manifestaron el prior y los monjes de Santa Engracia en un memorial remitido al monarca Fernando VI:

"Mas hallándose en el día con la novedad de venirse a tierra la fachada de la Yglesia, la que se adorna de la alaja más preciosa, que es una portada de piedra alabastro... la que es preciso desmontar, como también la sillería del Coro y órgano, y aver de derrivar todo el piso del Coro con las bóbedas de la superficie, como las de las naves de la iglesia, a causa de faltar la pared maestra, en que todo esto se afianza...la necesidad es la más instantánea y urgente, pues en el interin no se pueden celebrar los divinos oficios con la acostumbrada solemnidad..." 48 .

Las obras de reedificación de la iglesia alta comenzaron en 1755, a cargo de Fray Vicente Bazán, monje del monasterio. Pero este templo, y las modificaciones introducidas de forma concreta en el coro no las conocemos, si bien el testimonio dejado por Antonio Ponz, en su visita a Zaragoza en 1788, indica que esta renovación afectó de forma profunda al coro, hasta transformarlo por completo. Decía Ponz: "El coro de este Convento de Santa Engracia era, como su antigua iglesia, del estilo gótico, con escudos de armas de los Reyes Católicos, pero ya no existe con motivo de la renovación del Templo".

En cualquier caso, sabido es que este nuevo templo fue destruido por los franceses durante el Primer Sitio de Zaragoza ${ }^{49}$.

\section{LAS VIDRIERAS DEL CORO DE SAN- TA ENGRACIA}

Aunque las vidrieras del coro no se conservan, a través de las disposiciones del contrato es posible conocer algunas características formales, técnicas e iconográficas de

${ }^{48}$ A. ANSÓN NAVARRO, "La reedificación barroco-clasicista de la Iglesia Alta del Real Monasterio de Santa Engracia (1755-1762), obra del arquitecto Fray Vicente Bazán", Aragonia Sacra, VII-VIII, 1992-1993. Monográfico a Santa Engracia, p. 174.

${ }^{49}$ Es Arturo Ansón quien recoge las palabras de Antonio Ponz. Ibídem, pp. 173 y 179-190. 
estas obras, así como el valor y función de las mismas en el contexto de esta manifestación artística en la España de la época.

En la capitulación firmada entre el prior de Santa Engracia y el vidriero Francisco de Valdivieso se habla de tres vidrieras con sus correspondientes motivos figurativos. Una de ellas había de cerrar la ventana circular situada encima de la silla del coro que ocupaba el prior. Esta vidriera había de representar "un crucifixo con Sant Johan y Nuestra Senyora a los lados y al pie ha de estar la Magdalena" (Apéndice documental, doc. $\mathrm{n}^{\mathrm{o}} 1$ ). Hemos de imaginar una vidriera con la Madre de Jesús y su discípulo favorito, junto a María Magdalena, que suele aparecer con frecuencia en esta escena mostrando evidentes signos de dolor ${ }^{50}$.

No parece casual que la Crucifixión se situase en la vidriera situada encima de la silla prioral. Su papel sería recordar el sacrificio de Cristo y más concretamente la responsabilidad y compromiso de los priores en la imitación de Jesús. En este sentido, cabe mencionar el testimonio del Padre Sigüenza que al aludir a la pintura de Sebastiano del Piombo que decoraba el lienzo de muro situado sobre la silla del Prior en el monasterio de San Lorenzo de El Escorial y en la que aparece Cristo llevando la cruz, subraya que tal pintura constituye "un antidoto contra la vanidad del hombre" y que "se puso en lugar tan insigne y tan a propósito, y no sin consideración, para que los Prelados entiendan que aquella silla no tiene menor censor ni menor carga que la imitación de aquel Señor, Príncipe de los pastores, que llevó sobre sus hombros la Cruz donde se pagaron los daños que hicieron y hacían sus ovejas" ${ }^{51}$.

En la segunda vidriera se ejecutó la figura de San Jerónimo, doctor de la Iglesia latina y patrón de la orden monástica a la que se encomendó el cenobio de Santa Engracia.

${ }^{50}$ L. RÉAU, Iconografía del arte cristiano. Iconografía de la Biblia. Nuevo Testamento, Madrid, 1996, Tomo 1/ Vol. 2, pp. 518-521.

${ }^{51}$ P. Fray J. SIGÜENZA, Op. cit., p. 321.
En este caso se optó por la iconografía que presenta a San Jerónimo como sabio y doctor de la Iglesia "sentado en su scriptorio" acompañado "de sus frayres" (Apéndice documental, doc. $\mathrm{n}^{\mathrm{o}} 1$ ). Esta escena coincidiría con la pintada en uno de los cuadros del coro del monasterio de San Lorenzo de El Escorial en el que, en palabras del Padre Sigüenza, "está el santo leyendo a sus religiosos, declarándoles la Santa Escritura, como él mismo afirma que lo hacía" ${ }^{52}$. En esta misma vidriera aparecían las armas reales, que se repiten en el tercer ventanal mencionado en el contrato y que constituyen el testimonio de la protección y patrocinio regio, gracias al cual se edificó el conjunto monástico.

La última vidriera se dedicó a la patrona del monasterio Santa Engracia, a los Innumerables Mártires y a San Lamberto. No era este ventanal el único lugar donde se desarrolló tal iconografía. El padre Martón nos cuenta en su historia del monasterio que existía una pintura sobre tabla de la santa en la que ésta aparecía sentada "con una Azuzena en la mano derecha, teniendo à la siniestra à su Hijo; y que à dos Coros puestos de rodillas, la cercan los Martyres del Epigrafe. Trahen al lado izquierdo un Pendòn blanco, divisando su Campo una Cruz roxa; con la cabeza en las manos S. Lamberto" ${ }^{\prime 53}$. Asimismo, en el atrio que daba acceso a la cripta, tras la reforma de 1789, pintó el artista Francisco Ponzano una obra con los mismos protagonistas ${ }^{54}$.

No se especifican los detalles concretos de esta figuración, con la excepción de

${ }^{52}$ Ibídem, pp. 322-323.

${ }^{53}$ P. Fray L. B. MARTÓN, Op. cit., p. 182.

${ }^{54}$ Descrita por Faustino Casamayor en sus Años Políticos, recogido por A. SAN VICENTE, Años artísticos de Zaragoza 1782-1833 sacados de los Años Políticos e Históricos que escribía Faustino Casamayor. Estas obras son mencionadas por Wifredo Rincón en su estudio sobre la iconografía de Santa Engracia y los Innumerables Mártires. W. RINCÓN GARCÍA, "Aproximación a la iconografía aragonesa de Santa Engracia y de los Innumerables Mártires de Zaragoza", Aragonia Sacra, VII-VIII, 19921993. Monográfico Santa Engracia, pp. 401-402. 
que cada imagen estaría cobijada por un tabernáculo. Hemos de imaginar una representación que seguiría, en líneas generales, la forma usual de mostrar a estas figuras sagradas, con una joven Santa Engracia, vestida con el atuendo de las vírgenes y mártires y la cabeza descubierta con diadema o corona. Además, se plasmarían en vidrio los atributos que la identificarían, la palma de martirio, la columna, el clavo a los que se podrían haber añadido tal vez los instrumentos de su martirio: el martillo o la cuerda. Acompañarían a la Santa titular algunos de los Innumerables Mártires que tradicionalmente se representan junto a ella, tal como se recoge en el contrato, donde se indica, de forma vaga, que se realizarían las figuras que cupieran ${ }^{55}$.

Finalmente, se alude en el contrato a la representación de San Lamberto en esta misma vidriera. Este santo labrador zaragozano, muy venerado en todo Aragón, solía aparecer con su cabeza cortada en las manos.

Hay que señalar otras vidrieras del monasterio con los mismos protagonistas. Dichas vidrieras se encontraban en el refectorio y fueron encargadas el 22 de agosto del año 1500 al vidriero Severí Desmanes. Aunque esta iconografía no aparece recogida en el contrato, sí fue citada de forma explícita por el padre Martón en su historia del cenobio:

"Hizieronse por este tiempo las seis Vidrieras tan celebres, que registramos en el Refectorio, notando la Historia manuscrita, que tienen todas ellas seiscientos y diez y ocho palmos; pero de coloridos tan vistosos, y perfectos, que no acaban de ponderarlas los Artifizes, y que mejor entienden tal calidad de colores...siendo mas de admirar sus perfectissimas Imágenes de Santa Engracia, sus Compañeros, San Lamberto, y otros Santos; con varios Escudos Reales de los que usava el Rey Catholico" ${ }^{\prime 56}$.

${ }^{55}$ W. RINCÓN GARCÍA, Op. cit., pp. 406, 414-415.

${ }^{56}$ P. Fray L. B. MARTÓN, Op. cit., p. 498. El contrato de estas vidrieras fue inicialmente recogido, si bien solo parcialmente, por Manuel Abizanda. Su publicación
También en los ventanales del refectorio las imágenes de los santos estarían alojadas en templetes y apoyarían en su correspondiente peana, aunque en este caso cada capilleta acogería a dos figuras sagradas. Asimismo, al igual que sucedía en el coro, no faltaban en estas vidrieras del refectorio las armas reales ${ }^{57}$.

Pocos datos nos proporciona el contrato firmado entre el prior de Santa Engracia y el vidriero Francisco de Valdivieso acerca de las características técnicas o formales de las vidrieras que el artista ejecutó para el coro. Tan solo se alude en el documento a la calidad de las mismas, pues habían de ser "muy perfectas y de muy buen vidrio y colores". Ningún pormenor se señala acerca de dichos colores, lo que suscita algunos interrogantes y permite formular ciertas hipótesis.

El padre Martón, al hablar del coro del monasterio incide en que es "una pieza muy alegre, y llena de luzes" 58 . Esta iluminación se lograba gracias al vano circular, situado

íntegra se debe a M. A. PALLARÉS JIMÉNEZ, “Dos noticias acerca de la iconografía de San Lamberto: las vidrieras del refectorio del monasterio de Santa Engracia, y las bulas y estampas fraudulentas del impresor Pedro Hardouyn", Aragonia Sacra, IX, 1994, pp. 71 y 8586. En estas fuentes este vidriero es llamado Severí de Avignon. El propio Pallarés rastrea los trabajos de este artista francés en Cataluña, así como su llegada a Aragón en el año 1496. Ibídem, pp. 70-71. También aparece mencionado por Víctor Nieto, quien recoge un informe de la catedral de Tarragona del año 1496, en el que se hace referencia a la capacidad de Severí Desmanes, al que el llama Severi Dermasnes, para hacer vidrieras y reparar las antiguas. V. NIETO ALCAIDE, La vidriera española. Ocho siglos de luz..., p. 18. Hoy se sabe, gracias a las investigaciones realizadas sobre la vidriera medieval en Cataluña, que este maestro vidriero era natural de Châlons (Francia). Además de los trabajos ya mencionados, realizó en 1494 la vidriera del Juicio Final de la iglesia de Santa María del Mar de Barcelona. Ibídem, p.120; R. ALCOY PEDRÓS, “La evolución de la vidriera en la Cataluña medieval", en X. BARRAL I ALTET, (dir.), Vidrieras medievales en Europa, Barcelona, 2003, p. 177. ÍDEM, Vidrieras medievales de Cataluña, Barcelona, 2000, pp. 19 y 90.

${ }^{57}$ Así lo señaló Vicencio Blasco de Lanuza en el año 1622. R. ALCOY PEDRÓS, Op. cit., p. 71.

\footnotetext{
${ }^{58}$ P. Fray L. B. MARTÓN, Op. cit., p. 711.
} 
encima de la silla del prior, de gran tamaño, y a otras cuatro ventanas cuadradas de quince pies de alto y quince de ancho cerradas todas con sus correspondientes vidrieras. Este sistema de iluminación rompía con el muro translúcido del período gótico, apostando por unos vanos de menores dimensiones, alternados en una pared de obra que gana superficie. Los vanos cerrados por vidrieras se convertirían en la iglesia del monasterio cesaraugustano, y por extensión en el coro de la misma, en puntos de iluminación coloreados, alternados en una disposición rítmica regular con el paramento opaco ${ }^{59}$.

La descripción mencionada, así como las características de la vidriera española de la época, hacen pensar en el uso de vidrios de mayores proporciones que los utilizados en siglos anteriores en este campo artístico, con menos tiras de emplomado y de un colorido más claro. La representación de las figuras y escenas recogidas en el contrato exigiría el empleo de colores de mufla y especialmente de una grisalla de trazo menos grueso, para conseguir una representación naturalista, con efectos volumétricos similares a los alcanzados en el campo de la pintura.

En el contrato firmado por el propio Francisco de Valdivieso y el prior de Santa Engracia para la ejecución de la vidriera del canciller Jean de Sauvage, el día 12 de enero de 1519, se recogen con mayor detalle algunos aspectos relativos a las características del vidrio. La enumeración de tales aspectos permite deducir algunas ideas que confirman la adaptación de esta vidriera, y

\footnotetext{
${ }^{59}$ Víctor Nieto alude a este sistema adoptado en el modelo de iglesia frecuente en la época de los Reyes Católicos, formada por una nave con capillas entre los contrafuertes. En este tipo de iglesia, al que se acomoda el templo del monasterio de Santa Engracia, el contrarresto de los empujes generados por la bóveda de crucería se hace mediante contrafuertes, lo que determina la reducción de los vanos y el aumento del muro. La iglesia se estructura como una caja cerrada y mensurable, abarcable y modulada con una iluminación rítmicamente distribuida a lo largo del muro sólido. V. NIETO ALCAIDE, La vidriera española. Ocho siglos de luz..., pp. 124-125.
}

posiblemente las del coro, a los rasgos generales de esta faceta artística en la época. La insistencia en el uso de buen vidrio se repite en este documento, pero también se señala que la vidriera ha de ser blanca y de buenos colores. Estas disposiciones nos hablan del uso de planchas vítreas transparentes y de abundante color de mufla para representar las armas heráldicas del canciller ${ }^{60}$.

Pero, sin duda, son las vidrieras realizadas por Francisco de Valdivieso en la catedral de Huesca entre 1516 y 1519, las que permiten una aproximación directa a las características posibles de sus homólogas sitas en el coro del monasterio cesaraugustano (Figs. 1 a 8). En la actualidad, se conservan dos de las vidrieras realizadas por el mencionado artista para la seo oscense. Corresponden al cerramiento de dos vanos circulares situados en los extremos del transepto. Una de estas vidrieras, dedicada al Bautismo de Cristo (Fig. 2), se halla pendiente de restauración, y su deterioro, evidente y preocupante, afecta sobre todo a los rostros de algunas de las figuras representadas, lo que dificulta sobremanera la percepción de los detalles. La segunda de ellas recoge la escena de la Ascensión de Jesús (Fig. 3). Esta vidriera ha gozado de una mejor suerte, pues ha sido objeto de una rigurosa y muy cuidada restauración a cargo del taller vidriero Vitrales Huesca, con excepcionales resultados. La vidriera de La Ascensión se encuentra hoy en una capilla de la catedral de Huesca, a la espera de ser ubicada en su emplazamiento original en el ventanal, y esta circunstancia inusual permite apreciar, directamente y en primer plano, la gran calidad artística de la obra y la admirable capacidad de su artífice. Como se ha dicho en las líneas superiores, nos encontramos ante una vidriera en la que los colores de mufla tienen una importancia sobresaliente, y especialmente la grisalla, utilizada con una soberbia habilidad para delinear los rasgos faciales o los detalles del cabello. Las figuras muestran rostros expresivos y cercanos a modelos renacentistas,

\footnotetext{
${ }^{60}$ AHPZ, Notario Miguel de Villanueva, fols. 28r-29r.
} 
que nos hablan de un artista conocedor de las nuevas corrientes venidas de Italia. Un gran dibujante que domina a la perfección la técnica de trabajo del vidrio. El resultado es un vitral muy cercano a los valores de modelado y claroscuro propios de la pintura y en el que no se han descuidado los detalles aparentemente nimios, de forma que hasta la vegetación se ha trabajado con delicados trazos negros de grisalla. Por otro lado, los colores de crisol más densos, azules, verdes, rojos, contrastan con el tono dorado del amarillo de plata, presente en cabellos, nimbos, vestiduras o paisaje y que dota al conjunto de una atmósfera cálida y luminosa (Figs. 4 a 8). Estas características coinciden con la apuntadas en su momento por Víctor Nieto, que considera a Francisco de Valdivieso un maestro con un estilo propio y específico, en el que aúna soluciones tradicionales con una particular y original manera de interpretar las fórmulas cuatrocentistas ${ }^{61}$

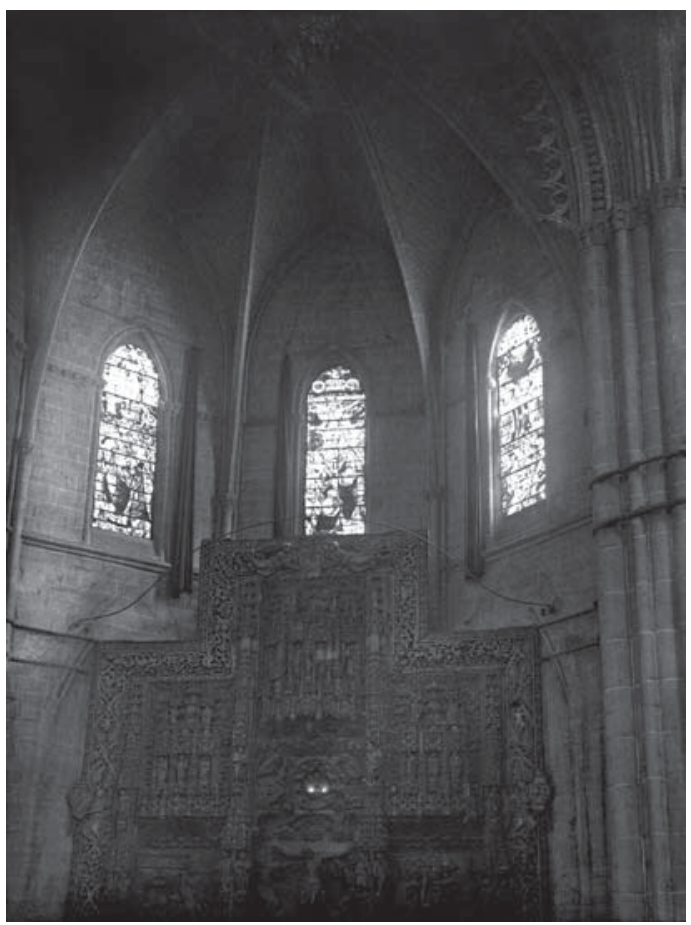

- Figura 1. Vidrieras del ábside de la catedral de Huesca. Foto: Ricardo del Arco. Fototeca. Diputación Provincial de Huesca.

${ }^{61} \mathrm{~V}$. NIETO ALCAIDE, La vidriera española. Ocho siglos de luz..., pp. 27-28.

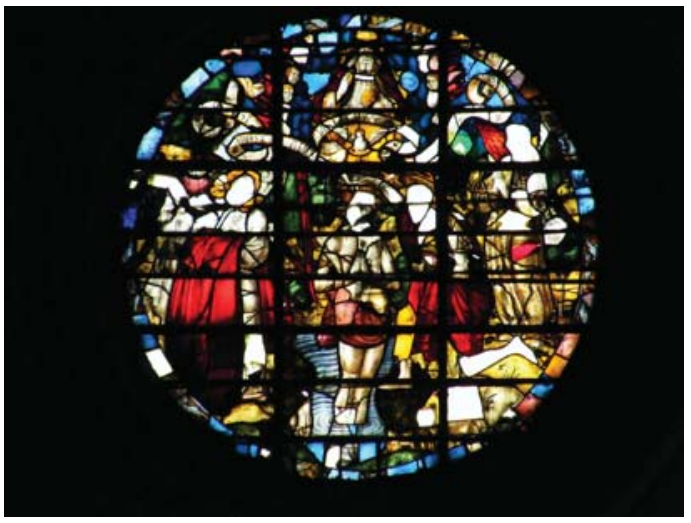

- Figura 2. Vidriera del Bautismo de Cristo. Transepto de la catedral de Huesca. Foto: Vitrales Huesca.

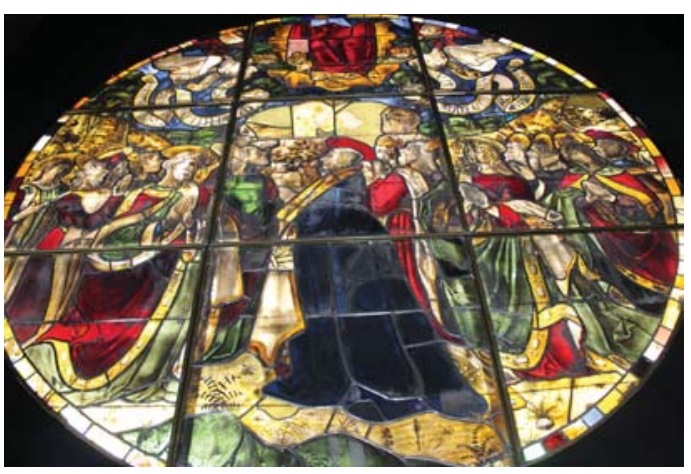

- Figura 3. Vidriera de la Ascensión. Transepto de la catedral de Huesca. Foto de la autora.

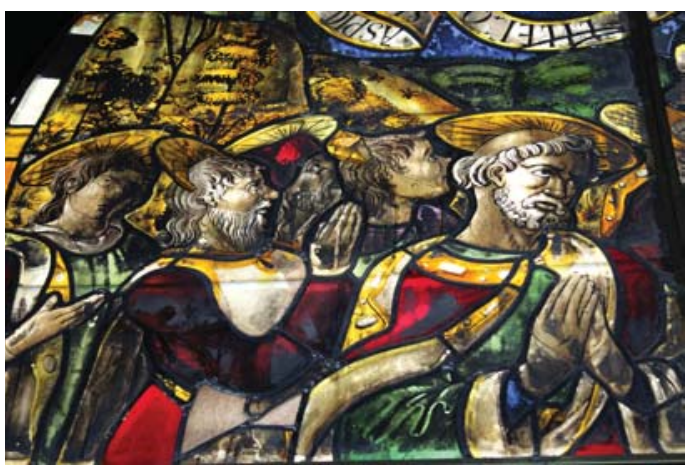

- Figura 4. Vidriera de la Ascensión. Detalle. Transepto de la catedral de Huesca. Foto de la autora. 


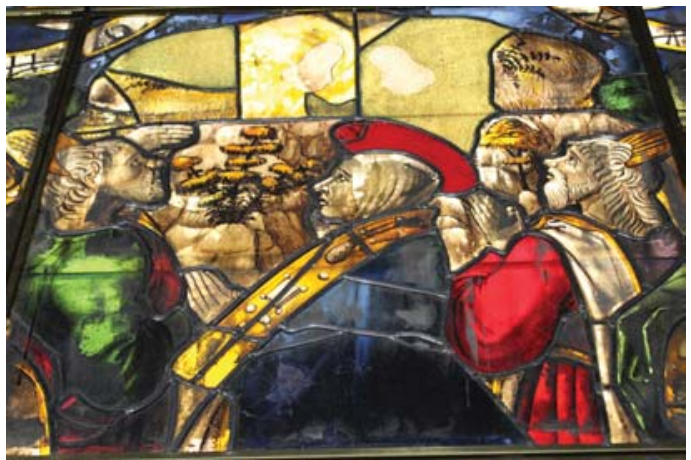

- Figura 5. Vidriera de la Ascensión. Detalle. Transepto de la catedral de Huesca. Foto de la autora.

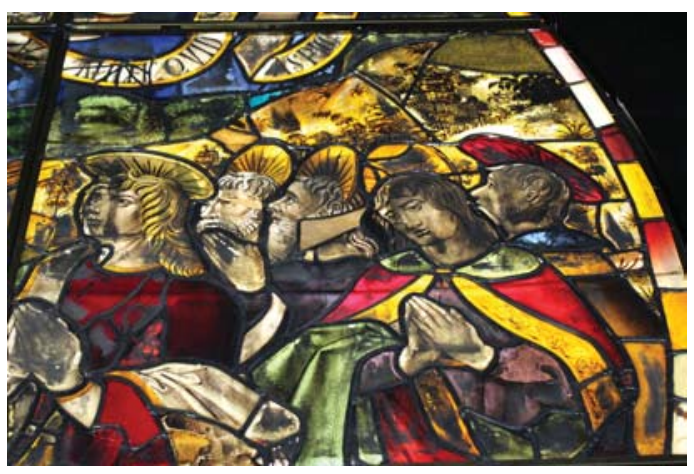

- Figura 6. Vidriera de la Ascensión. Detalle. Transepto de la catedral de Huesca. Foto de la autora.

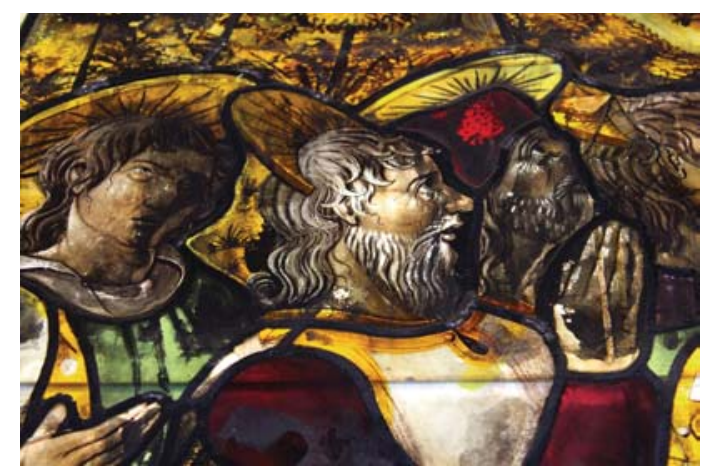

- Figura 7. Vidriera de la Ascensión. Detalle. Transepto de la catedral de Huesca. Foto de la autora.

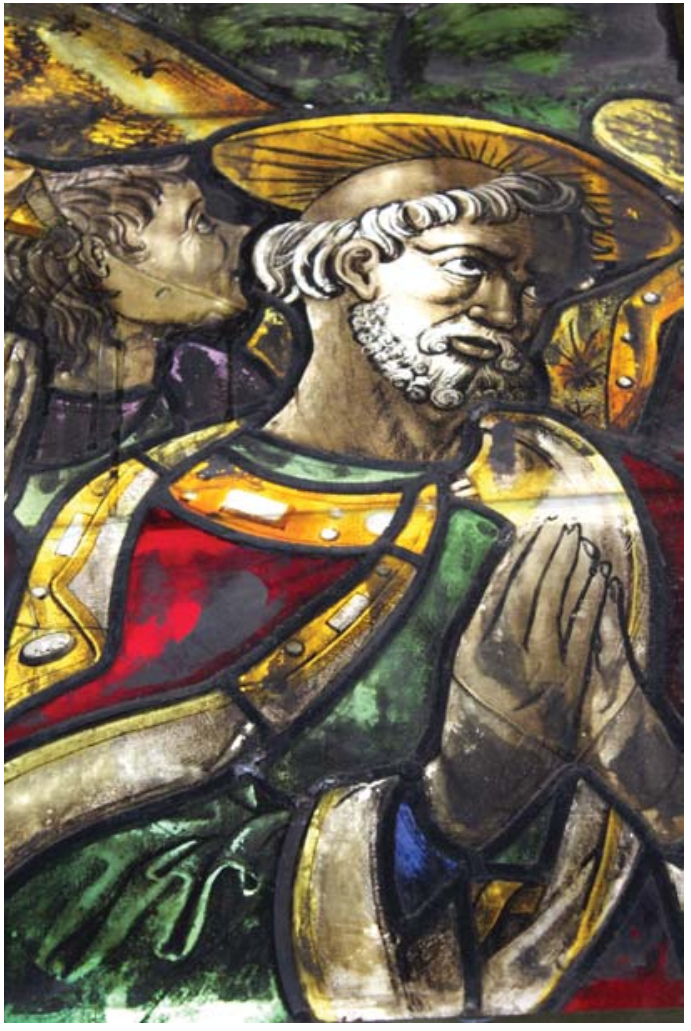

- Figura 8. Vidriera de la Ascensión. Detalle. Transepto de la catedral de Huesca. Foto de la autora.

En el contrato firmado con Francisco de Valdivieso para la ejecución de las vidrieras de Santa Engracia se insistía en el uso de vidrios de buena calidad y, ciertamente, este no era un tema baladí. La bondad y resistencia del material constituían la mejor garantía para una idónea preservación futura de la vidriera ${ }^{62}$. Para el caso aragonés, hay noticias acerca de la comercialización y fabricación de vidrio a lo largo del siglo XV, incluso es posible que con anterioridad ${ }^{63}$. Sin embargo, no parece que existiera una

${ }^{62}$ En esta época la resistencia del vidrio podía entrar en colisión con la exigencia de una mayor transparencia, lo que podía disminuir el calibre del mismo y propiciar su deterioro. Ibídem, pp. 26-27.

${ }^{63}$ Miguel Ángel Pallarés menciona las noticias que, acerca de la compra de vidrio en Zaragoza y en Teruel, se recogen en un libro de fábrica de La Seo en 1346, si bien no es posible afirmar con seguridad si este dato se refiere a vidrio propiamente dicho o a cerámica vidriada. M. A. PALLARÉS JIMÉNEZ, Op. cit., pp. 68-69. 
industria floreciente en este campo en Aragón. No hubo una producción cuantitativa ni cualitativamente importante y tampoco se desarrolló un trabajo artístico autóctono en el campo de la vidriera ${ }^{64}$. De esta forma, en el caso de Santa Engracia, como ocurría en el arte de la vidriera en España durante este período, hemos de hablar de un vidrio importado. Víctor Nieto enfatiza esta circunstancia particular, aludiendo a la adquisición de las materias primas directamente por el artista vidriero o a través de mercaderes. El vidrio fue objeto de una actividad comercial, que estaría libre de impuestos cuando se destinaba al cierre de los ventanales de un recinto religioso ${ }^{65}$.

No cabe duda que las vidrieras realizadas en Santa Engracia convirtieron a este monasterio en un conjunto excepcional en cuanto al florecimiento y desarrollo de esta manifestación artística en Aragón. Desde un punto de vista cuantitativo, el recurso a la vidriera fue notable en el cenobio cesaraugustano, pues este tipo de cierre del ventanal se eligió para los vanos del refectorio, en el que el citado Severí Desmanes realizó seis vidrieras, y también para hacer lo propio en los ventanales del coro, con al menos tres vidrieras realizadas por Francisco de Valdivieso. A estas vidrieras habría que unir la ejecutada por el propio Valdivieso en la capilla del canciller Jean de Sauvage en el año 1519.

${ }^{64}$ Ibídem, p. 67. Carmen Gómez Urdáñez habla de un primer horno de vidrio que se instaló en la ciudad de Zaragoza en el año 1566, más allá del Puente de Piedra, pero en el que parece se habrían de fabricar piezas de vajilla. C. GÓMEZ URDÁÑEZ, Arquitectura civil en Zaragoza en el siglo XVI, Zaragoza, 1987, Tomo I, p. 134. De hecho, esta situación queda refrendada en el caso de Santa Engracia, donde, como se ha visto, los vidrieros que trabajaron eran de origen castellano o francés, si bien en el caso de Severí Desmanes su llegada a la capital aragonesa vino precedida por su afincamiento en Cataluña.

${ }^{65}$ Víctor Nieto habla de la llegada de vidrio procedente de Flandes y de su comercialización en ferias. V. NIETO ALCAIDE, La vidriera española. Ocho siglos de luz..., p. 27 e ÍDEM, La vidriera del Renacimiento en España..., p. 16.
Las vidrieras del monasterio de Santa Engracia se insertan en un contexto temporal, el siglo XVI, en el que esta manifestación floreció en España de forma especial. Fue el desarrollo de nuevas empresas constructivas, en las que pervivió la tradición gótica, lo que propició el surgimiento de talleres vidrieros, que ensayaron nuevas soluciones técnicas y formales relacionadas con la introducción de un lenguaje renacentista, fenómeno que contemporáneamente se estaba produciendo en otros campos como la escultura o la pintura. Un factor determinante fue la pervivencia, al menos en los dos primeros tercios del siglo XVI, de un concepto espacial en el que el color jugaba un papel fundamental. De esta forma, la vidriera se convirtió en un vehículo privilegiado para crear ámbitos con un luz transformada, coloreada ${ }^{66}$.

Sin embargo, en Aragón la extensión e importancia alcanzada por la vidriera en el monasterio de Santa Engracia resulta singular. No había vanos cerrados mediante vidrieras en la arquitectura civil de la época. En la arquitectura doméstica, se ha documentado el uso de papeles cubiertos de cera denominados encerados que se insertaban en los marcos o aros de las ventanas ${ }^{67}$. En el siglo XVII todavía algunos viajeros, en su periplo peninsular, subrayan la pervivencia de éste o similares procedimientos de cerramiento en distintos lugares de España. Así lo hace Bartolomé Joly en 1603-1604 durante su estancia en la ciudad de Valencia, cuando alude a la escasez y estrechez de los vanos de las viviendas acomodadas, en las que no ha-

${ }^{66}$ V. NIETO ALCAIDE, La vidriera del Renacimiento en España..., pp. 9-10. Este autor subraya que esta preferencia por el color puede rastrearse también en la pintura, en la que persisten todavía los fondos dorados o en la escultura en madera dorada y policromada. Podrían añadirse otras manifestaciones a través de las cuales el color se hizo presente en el espacio religioso: revestimientos cromáticos en la arquitectura, textiles, orfebrería, etc.

${ }^{67}$ Carmen Gómez apunta que el vidrio comenzó a utilizarse en las viviendas europeas a partir de 1550 y no se generalizó hasta el siglo XVIII gracias a la mejora de los procedimientos de fabricación de este material. C. GÓMEZ URDÁÑEZ, Op. cit., Tomo I, p. 134. 
bía vidrios, "sino tela encerada, lo que hace muy bien cuando está nueva, pero que se oscurece y pronto carga de polvo". En 1611, a Jacobo Sobieski le llama la atención que en Logroño haya lienzos en las ventanas en lugar de cristal, costumbre que el atribuye a un intento de evitar el calor. Dice así: "Para evitar los calores del sol e impedir su invasión en el interior de las casas, se ponen lienzos en las ventanas en lugar de cristales. Esta costumbre no contribuye tanto a la alegría de un palacio como los cristales en las ventanas ${ }^{\prime \prime 68}$.

Tampoco fue la vidriera un procedimiento de cierre habitual en la arquitectura religiosa de Aragón. El alabastro se convirtió en el material preferido para tal cometido ${ }^{69}$.

${ }^{68} \mathrm{~J}$. GARCÍA MERCADAL, Viajes de extranjeros por España y Portugal, s. 1., 1999, Tomo II, p. 711 y Tomo III, p. 179. Según la condesa D' Aulnoy ni siquiera el Palacio Real de Madrid tuvo cierres acristalados hasta bien entrado el siglo XVII. La dama se sorprende, en la crónica de su viaje por España realizado entre 1679 y 1680, de la mezquindad de los vanos de tan importante edificio, así como de la ausencia de cristales, que ella atribuye al elevado precio del vidrio. D'AULNOY, Viaje por España en 1679 y 1680 y cuentos feericos, Barcelona, 1962, volumen I, p. 208. Cierto es que algunos estudiosos consideran que la condesa D'Aulnoy se basa en la narración de un viajero anterior, Bertaut, y no en su propia observación, sin embargo, los mismos especialistas señalan que sería por esta época cuando se adquirieron cristales venecianos y se procedió a su instalación en los ventanales del Palacio, tarea muy avanzada, pero todavía no concluida en 1679. Duque de MAURA y A. GONZÁLEZAMEZÚA, Fantasías y realidades del viaje a Madrid de la condesa D'Aulnoy, Madrid, s. f., p. 189. Por otro lado, José Deleito y Piñuela manifiesta que la presencia del vidrio no era tan raro como suelen subrayar los viajeros extranjeros, pues escritores como Zabaleta o doña Mariana Carabajal, hablan de ellos como algo corriente en casas principales. J. DELEITO Y PIÑUELA, La mujer, la casa y la moda:(en la España del rey poeta), Madrid, 1946, p. 89.

${ }^{69}$ Miguel Ángel Pallarés hace una relación exhaustiva del uso del alabastro en edificios religiosos durante el siglo XVI. Inusual debió de ser el empleo de "ojas de cuerno teñidas de colores" en el convento cesaraugustano de Santo Domingo. M. A. PALLARÉS JIMÉNEZ, Op. cit., p. 70. Sin duda hay que destacar por su importancia el conjunto de ventanales de alabastro de la catedral de Tarazona, que constituye un ejemplo excepcional que posibilita el análisis de la integración del vano, y el sistema de iluminación que genera, en el contexto arqui-
No obstante, además de las vidrieras de la catedral oscense, a las que ya se ha aludido, están documentadas las vidrieras traídas desde Barcelona en 1448 para el cierre de los ventanales del coro, del refectorio y de la capilla parroquial de San Miguel de la seo cesaraugustana, cuya hechura corrió a cargo del maestro Thierry Demés o de Metz, llamado en la documentación Terri de $\mathrm{Mes}^{70}$; y las del claustro del monasterio de Jerusalén de Zaragoza, tal como figura en el acuerdo de 1489 por el que Pere Antonii se compromete a construir dicho claustro con vidrieras ${ }^{71}$.

La preferencia por el alabastro no es difícil de explicar. La facilidad con la que el material se extraía de las canteras, entre las que destacan las de Gelsa; su tonalidad blanca brillante y su carácter translucido similar al del mármol, así como su idoneidad para dividirlo en láminas, determinaron su extensión y primacía ${ }^{72}$.

En este contexto, cabe preguntarse por qué en el monasterio de Santa Engracia se optó por un cerramiento con vidrieras,

tectónico. C. GÓMEZ URDÁÑEZ, “Desde la Restauración, Estudio Histórico-Artístico. La configuración de una obra del Alto Renacimiento", en Decoración mural de la Catedral de Santa María de la Huerta de Tarazona. Restauración 2008, Zaragoza, 2009, pp. 47-48.

${ }^{70}$ A. GASCÓN DE GOTOR, La Seo de Zaragoza. Estudio histórico-arqueológico, Barcelona, 1939, p. 40. Thierry Demés o de Metz fue uno de los maestros vidrieros venidos a Cataluña en el siglo XV y que se encargaron de la reparación de ventanales dañados, así como de la introducción de nuevas soluciones figurativas en esta manifestación artística. R. ALCOY PEDRÓS, Op. cit., p. 177.

${ }^{71}$ M. A. PALLARÉS JIMÉNEZ, Op. cit., p. 70 y doc. 22.

${ }^{72}$ El Diccionario de Autoridades señala que el término alabastrinas se empleaba para denominar "unas hojas, ò láminas delgádas de piedra que se llama alabastro; y se vsa de ellas en España para cerrar las clarabóyas de los templos, porque como son transparentes, entra bastante luz por ellas". Esta cita y las explicaciones acerca del uso y cualidades del alabastro han sido tomadas de J. CRIADO MAINAR y O. CANTOS MARTÍNEZ, "El alabastro, un mineral singular. Reflexiones sobre su uso en las artes plásticas y la construcción", en I. AGUILERA ARAGÓN y J. L. ONA GONZÁLEZ, Delimitación comarcal de Zaragoza, Zaragoza, 2011, pp. 257-261. 
a pesar de que en la tradición constructiva aragonesa el alabastro gozaba de un amplio predicamento. Varias son las hipótesis que cabe apuntar respecto a esta cuestión. Por un lado, al tratarse de un monasterio de patrocinio regio hay que considerar la obra de Santa Engracia más vinculada a las construcciones promovidas por la Corona que al contexto general de la edilicia en Aragón durante este período. Hay que tener en cuenta, además, que el prior que estaba al frente del cenobio cuando se realizaron las vidrieras era fray Martín de Vaca, que fuera monje profeso del monasterio de Santa María de la Sisla en Toledo. Era un religioso con conocimientos de arquitectura $^{73}$ y familiarizado con una práctica de edificación en la que la vidriera tuvo un papel importante.

Además, la vidriera era un medio idóneo para representar imágenes y escenas religiosas de cierta complejidad en el ventanal, así como para incorporar las armas heráldicas de la monarquía. El carácter colorista del vidrio, con las tonalidades cromáticas intensas de crisol, y los matices que el artista introduce con los colores de mufla, cada vez más presentes en esta época, resaltados además por el efecto de la luz que incide por la parte trasera del ventanal, lo convierten en un punto luminoso y cromático en contraste con la zona sombría del muro. Este epicentro radiante atraía la atención y subrayaba los motivos figurativos y heráldicos que las tintas configuraban y delimitaban.

Y ello a pesar de que las láminas de alabastro usadas en las ventanas de edificios religiosos también recibieron policromía en algunos casos, y así, mediante la adición del color fue posible ejecutar motivos figurativos o de otra índole. De hecho, la pintura permitía unos efectos naturalistas similares a los conseguidos en otros soportes, con el añadido de que las juntas finas de las piezas de alabastro permitían una unidad en los motivos que, en el caso de la vidriera se intentó alcanzar mediante el uso de placas ví-

${ }^{73}$ J. CRIADO MAINAR, J., "La fábrica del monasterio jerónimo de Santa Engracia...", p. 262. treas de un tamaño mayor que redujeran la necesidad de uso del emplomado. También en las láminas de alabastro, como ocurre con el vidrio, la luz exterior que atraviesa el material aviva el color y lo transforma creando zonas de fusión cromática y efectos tonales variados y difusos ${ }^{74}$.

En cualquier caso, las vidrieras realizadas en el coro del monasterio de Santa Engracia debieron de tener una importante trascendencia artística. Así parece demostrarlo el hecho de que fuera su artífice, Francisco de Valdivieso, el elegido para realizar los vitrales de la catedral de Huesca entre 1516 y $1519^{75}$. Decisión en la que pudo influir, no solo la calidad y buen hacer de este artista, patente en las obras aún conservadas en la seo oscense, sino también otros factores, como el hecho ya apuntado de que la iglesia parroquial de Santa Engracia perteneciese a la diócesis de Huesca o los vínculos familiares que unían al titular de la iglesia oscense, Juan de Aragón y Navarra, con el Monarca Católico.

\section{APÉNDICE DOCUMENTAL}

1

\section{5, julio, 13. Zaragoza}

Fray Martín de La Sisla, prior del monasterio jerónimo de Santa Engracia, capitula con el maestro vidriero Francisco de Valdivieso la hechura de tres vidrieras para las ventanas del coro de dicho cenobio por precio de 50 ducados. Contiene asimismo el albarán por el que Francisco Valdivieso otorga haber recibido 10 ducados correspondientes a la primera tanda del pago de las mismas.

74 Estas características del alabastro policromado son analizadas por Carmen Gómez Urdáñez al aludir a la vidriera de la Asunción del transepto de la catedral de Tarazona. C. GÓMEZ URDÁÑEZ, “Desde la Restauración, Estudio Histórico-Artístico. La configuración de una obra del Alto Renacimiento"..., pp. 194-195.

${ }^{75}$ R. del ARCO, Op. cit., p. 81 y A. DURÁN GUDIOL, Op cit., p. 139. 
Archivo Capitular de La Seo de Zaragoza (en adelante ACLSZ), Protocolos notariales, Notario Alfonso Francés, año 1515, fol. 52 .

Die XIII julii anno $\mathrm{M}^{\mathrm{o}} \mathrm{D}$ XVํo Cesarauguste.

Capitulacion y concordia fecha y concordia entre el senyor fray Martin de La Sisla, prior del monasterio de Sancta Engracia, de la vna part; e Francisco de Valdeuiesso, vidriero, (tachado: natural) \vezino de Vurgos/ ${ }^{76}$ de Castilla y agora hauitant en Caragoca, de la otra part, en et sobre las vidrieras que se han de fazer en la manera siguient.

Primo (tachado: ha de) da a fazer al dicho Francisco de Valdeuiesso el dicho prior tres vidrieras para las ventanas del coro ( $t a-$ chado: en la manera siguiente) de las historias siguientes: primo \en/ la vna vidriera que se ha de poner en la $\mathrm{O}$ del coro ha (tachado: de ser) hauer vn crucifixo, con Sant Johan y Nuestra Senyora a los lados, y al pie ha de star la Magdalena, las quales ymagines han de ser muy perfectas y de muy vidrio y buenas colores.

Item \en/ la otra vidriera ha de hauer vn Sant Iheronimo, como sta en su scriptorio con sus frayres \y al pie las armas reales/ muy perfectamente de ymagenes, vidrio $\mathrm{y}$ colores.

Item en la otra vidriera han de hauer Santa Engracia con Sant (tachado: Lupercio) Lambert y los (tachado: XV) que cupieren de los XVIII caualleros y encima de las ymagenes sten sus tabernaculos y al pie las armas reales de muy buen vidrio y de muy perfectas colores.

Item ha de dar acabadas \y asentadas/ todas las dichas tres vidrieras fasta Pascua de Nauidat primero vinient.

Item ha de star a cargo del dicho maestro todas las cosas necessarias para fazer las

\footnotetext{
${ }^{76}$ Las palabras que figuran entre barras oblicuas \/ aparecen sobrepuestas en el documento.
}

dichas vidrieras excepto las guarniciones y redes de fierro.

Item (tachado: ha de fazer) (tachado: dara) todas estas tres vidrieras han de ser muy perfectas y de muy buen vidrio y colores, a contentamiento del padre prior.

Item da el padre prior al dicho maestro por las dichas tres vidrieras cinquenta ducados pagaderos desta manera: los diez ducados luego (tachado: en) para empecar a fazer las vidrieras, los otros diez a la metat de la obra e el residuo fechas y asentadas que seran las dichas tres vidrieras.

Item es concordado entre las dichas partes que fechas que seran las dichas tres vidrieras hayan de tachar aquellas el dicho padre prior y Felip d'Ortal y si conoceran aquellas no valer los cinquenta ducados, que le quiten de los dichos cinquenta ducados lo que les parecera y el maestro se haya de \por tener por/ contento de lo que ellos tacharan y que mas el padre prior no le haya de pagar y si tambien parecera a los dichos prior y Felip Ortal que valer las dichas vidrieras mas de los cinquenta ducados, que le puedan tachar al dicho maestro mas de los dichos cinquenta ducados lo que les parecera, con esto que no le puedan tachar mas de fasta sesenta ducados e no mas.

Item es concordado que si el dicho Francisco de Valdiuieso no dara acabadas y asentadas, dandole las guarniciones y redes de fierro el padre prior, todas las dichas tres vidrieras en la forma suso dicha fasta el dicho tiempo de Pascua de Nauidat, que tenga de pena diez ducados de oro, los quales se le hayan de quitar de los dichos cinquenta ducados.

Testes Johan d'Arce e Pedro de Gabara, panicero, habitantes Cesarauguste.

Eodem die el dicho Francisco atorgo hauer resciuido del padre prior los diez ducados que luego le hauia de dar. E porque etc., atorgo el presente albaran etc.

Testes qui supra proxime. 
2

1515, septiembre, 24. Zaragoza

Fray Martín de La Sisla, prior del monasterio jerónimo de Santa Engracia, capitula con Pedro Laguardia, imaginero, la realización de las filacterias del coro y los florones de las claves de las bóvedas de dicho cenobio.

ACLSZ, Protocolos notariales, Notario Alfonso Francés, año 1515, fol. 61v.

Assimesmo le da a fazer las filateras del coro altas e vaxas de follages del romano, segunt esta en la muestra que fizo. Las cinco mayores han de ser a diez palmos de punta a punta con tres (ripadas?) que han de bolar todo lo que fuere menester e su scudo en medio llano.

Item las claues medianas han de ser de la mesma obra de las mayores que han de tener cinco palmos y medio fasta seis.

Item los florones han de ser de quatro palmos si lo cuffriere la obra de roja de veroa todo lo susodicho ha de ser muy bien acabado en toda perfeccion.

Item ha de dar el padre prior la madera que fuere menester y por las claues mayores se le han de pagar a quatro florines y por las medianas a dos florines y por los florones a diez sueldos, por lo qual se obligo de lo fazer en toda perfeccion. Han se le han de dar los dineros de la dicha obra como fuere acabando.

Testes qui supra [Jayme Serrat, pintor, Johan Santacruz, obrero de villa, habitantes en Caragoca].

3

1515, septiembre, 24. Zaragoza

Fray Martín de La Sisla, prior del monasterio jerónimo de Santa Engracia, capitula con Pedro Laguardia, imaginero, la realización de un Crucifijo.
ACLSZ, Protocolos notariales, Notario Alfonso Francés, año 1515, fol. 61r.

Die XXIIII septembris anno $\mathrm{M}^{\mathrm{o}} \mathrm{D}^{\mathrm{o}} \mathrm{XV}$ Cesarauguste.

Eadem die fray Martin de La Sisla, prior del monasterio de Sancta Engracia, dio a fazer a maestre Pedro La Guardia, imaginero, vn crucifixo de madera con las condiciones siguientes. Primerament ha de fazer el dicho crucifixo de madera de nozedo de ocho palmos \con su cruz/ de largo, muy bueno e muy perfecto, a contentamiento del padre prior $\mathrm{e}$, sino stouiere a su contentamiento, que se quede para el dicho maestro, e, si stouiere a su contentamiento, que sea tachado por dos maestros con esto que no puedan mas de fasta CC sueldos, de alli avaxo lo que les pareciere, y no le ha de dar fasta ser acabado, ha lo de dar acabado (tachado: por todo el anyo de) fasta Pascua Florida que viene.

Testes Jaime Serrat pintor, Johan de Sancta Cruz, obrero de villa, habitantes en Caragoca.

4

1524, septiembre, 11. Zaragoza

Concordia pactada entre Aldonza Albanel, viuda del vicecanciller Antonio Agustín, y el imaginero Pedro Laguardia por los trabajos de asentar el retablo y el rejado en la capilla que el matrimonio poseía en el monasterio jerónimo de Santa Engracia, acordando un precio de 12 ducados por dichos trabajos.

Archivo Histórico de Protocolos Notariales de Zaragoza, Notario Juan de Aguas, 1524, fols. 162r-v. Documento citado en M. L. MIÑANA et alii, "La capilla del Patrocinio...", p. 193.

Concordia echa entre la noble y muy magnifica Senyora donya Aldonca Albanell, vidua mujer que fue del muy magnifico y 
muy circunspecto micer Anthonio Agustin, vicecanceller del Rey nuestro Senyor, de la vna parte; y mastre Pedro Laguardia imaginero.

Et primeramente es concordado entre las dichas partes que el dicho mastre Pedro dentro tiempo de vn mes del presente dia contadero haya de dar assentado el retablo de (tachado: alabastro) \madera/ y rexado de yerro que tiene echo para la capilla que tiene en la iglesia de Sanctangracia (sic) en toda perfeccion y a todo probecho y seguridat segunt la obra lo requiere a conoscimiento de maestre Gil Morlans imaginero y del morisco.

Item es concordado entre las dichas partes que el dicho maestre Pedro sea obligado y se haya de poner toda la madera, andamios y gente que fuere menester para assentar el dicho retablo y rexado; y ha de hazer a sus costas dos barrones de hierro tan largos y gruessos quanto fueren menester para los dos pilares principales del rexado y mas ha de poner todos los golfos de yerro y spigas y otras cosas que seran menester para estar muy bien assentado el dicho rexado.

Item es concertado entre las dichas partes que la dicha Senyora donya Aldonca haya de paguar al dicho mastre Pedro por assentar la dicha obra doze ducados de oro paguaderos en tercios eguales el vno luego, el otro e medio echa la obra, el segundo tercio y el postrero tercio acabada la obra y que la dicha Senyora haya de dar asentada la bassa del dicho rexado y que le haya de dar otro tanto yerro como pesaran los barrones.

Die XI septembris anno M D XXIIII Cesarauguste fue firmada la dicha concordia por las dichas partes prometieron y juraron etc.

Testes Diego de Vera y \Joan/ Corral habitantes.

1518, septiembre, 15. Zaragoza

El capítulo de monjes del monasterio de Santa Engracia, reunido en la cámara del prior
Gabriel Casells, hace donación a micer Antón Agustín, vicecanciller del Rey, y a su mujer Aldonza Albanell de la capilla de la Coronación de la Virgen, otorgándoles permiso para construir en ella sus sepulturas y cisterna.

ACLSZ, Protocolos notariales, Notario Alfonso Francés, año 1518, fol. 100.

(Al encabezamiento: Die XV septembris anno $\mathrm{M}^{\mathrm{o}}$ quingentesimo decimo octauo Cesarauguste).

(Al margen: Donacio capelle Sancte Engracie).

Eadem die. Que plegado y ajustado el capitol y conuento de los muy reuerendos y venerables prior y frayres del monesterio de Sancta Engracia de la orden de senyor Sant Jeronimo de la ciudat de Caragoca en la cambra del prior en do etc., a son de canpana segunt es la costumbre, en el qual fueron presentes los siguientes: fray Grabiel Casells, prior; fray Johan Nauarro, fray Johan d'Alcantara, fray Pedro de la Vega, fray Francisco (ilegible), fray Johan de Tudela, fray Miguel Ortin, fray Miguel Serrano, fray Miguel Lupercio, fray Johan del Mas, fray Guillermo de Fuentes, fray Jeronimo de Mora; frayres del dicho monesterio de Sancta Engracia, capitulantes, capitol facientes y representantes y atendientes et considerantes los circumspectos et magnificos micer Anthon Agostin, vicecanceller del Rey nuestro Senyor, et Aldonca Albantel, coniuges, habitantes en Caragoca, en nombres suyos proprios tener mucha debocion en la iglesia de senyora Sancta Engracia et Deo dante fara mucho bien en dicha iglesia de Sancta Engracia, por tanto nos dichos prior, frayres y conuento queriendo cumplir su debocion y buena voluntat que a la dicha iglesia tiene de nuestras sciertas sciencias, damos a los dichos micer Anthon Agostin y Aldonca Albanell, coniuges, a los suyos y a quien el los querran huna capilla que sta junto con el altar mayor llamada de la Coronacion de Nuestra Senyora, ensemble con vna torre junto a ella a la parte del 
altar mayor y hun corral et patio a la part de fuera que tiene de la capilla de Felip Artal desde la torronada o torre de la iglesia en la qual torre (repetido: torre) pueda fazer su sepultura y en el patio y corral la cisterna o cisternas, la qual capilla affruenta con la sacristia y con la capilla de Luys Goncalbez (Serrat?), la qual capilla vos damos para vos y a los parientes vuestros et a cada huno de vos largament etc., la qual donacion de la dicha capilla vos fazientes no obstant qualesquiere priuilegios e statutos de la dicha iglesia largament.

Testes los honorables mossen Pedro Maganya, clerigo, et Johan de Meteli, mercader, habitantes en Caragoca. 